\title{
Provenance of Upper Cretaceous quartz-rich sandstones from the North Sudetic Synclinorium, SW Poland: constraints from detrital tourmaline
}

\author{
Julita BIERNACKA
}

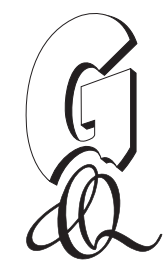

\begin{abstract}
Biernacka J. (2012) - Provenance of Upper Cretaceous quartz-rich sandstones from the North Sudetic Synclinorium, SW Poland: constraints from detrital tourmaline. Geol. Quart., 56 (2): 315-332, doi: 10.7306/gq.1024

Upper Cretaceous quartz arenites that fill the North Sudetic Synclinorium on the northern periphery of the Variscan Bohemian Massif show high compositional but low textural maturity. They have been interpreted for years as derived largely from nearby granite plutons, i.e. as first-cycle sediments. A different provenance was revealed on the basis of a combined light and heavy mineral analysis, and particularly a detrital tourmaline study, given that tourmaline is a sensitive indicator of granitic/metamorphic/sedimentary (multi-recycling) origin. Cenomanian, Turonian, Coniacian and Santonian sandstones contain abundant angular tourmaline grains, together with zircon and rutile, and subordinately staurolite, garnet, anatase, kyanite, sillimanite and monazite. The successive - Cenomanian to Santonian tourmaline populations are similar with regard to shape, colour and chemical composition. The latter points unambiguously to various metamorphic rocks with a predominant group of Al-rich metapelites (Al-rich, F-poor dravite). It is concluded that, in the Late Cretaceous, large Sudetic granite plutons such as the Karkonosze and Strzegom-Sobótka massifs were not exposed but were buried under a thick siliciclastic cover. These results coupled with published apatite fission-track data from the granitic Karkonosze Pluton and the gneissic/migmatitic Góry Sowie Massif reveal that Late Cretaceous quartz arenites of the North Sudetic Synclinorium reflect gradual exhumation of the surrounding massifs, but do not record the final exposure of crystalline rocks. Since the latest Turonian, this exhumation corresponded to the Late Cretaceous inversion episode in Central Europe. The textural immaturity of Upper Cretaceous sandstones is misleading in terms of their recycled origin, and it is inherited from immature clastic source rocks.
\end{abstract}

Julita Biernacka, Institute of Geology, University of Poznań, Maków Polnych 16, 61-606 Poznań, Poland; e-mail: julbier@amu.edu.pl (received: May 11, 2011, accepted: March 14, 2012; first published online: May 29, 2012).

Key words: quartz arenites, provenance, heavy minerals, tourmaline, Sudetes Mts., Late Cretaceous, inversion.

\section{INTRODUCTION}

Upper Cretaceous sandstones filling sedimentary basins within the Bohemian Massif are dominated by mature to supermature quartz-rich arenites (Skoček and Valečka, 1983; Milewicz, 1997, 1998; Wojewoda, 1997; Uličný, 2001; Götze and Siedel, 2007; Caracciolo et al., 2011). Quartz arenites as the end-products of sandstone evolution are generated either by multiple recycling of older siliciclastic deposits, or by an exceptional combination of tropical climate, low relief and slow sedimentation rate producing first-cycle arenites from crystalline source rocks (Suttner and Basu, 1981). The latter process, although rare, has been documented from both recent (Johnsson et al., 1991) and ancient environments (Avigad et al., 2005; van Hattum et al., 2006; Bernet et al., 2007). None of the above scenarios can be excluded a priori in the case of the Upper Cretaceous sandstones. A long-term greenhouse climate with subtropical conditions in Central Europe in the
Cenomanian (Falcon-Lang et al., 2001) and the peneplained Bohemian Massif covered with deep weathering zones (Kužvart and Konta, 1968; Migoń and Lidmar-Bergström, 2002) created favourable conditions for the origin of first-cycle quartz arenites. On the other hand, the northern part of the Bohemian Massif might have been buried under a thick sedimentary cover of Late Variscan to post-Variscan age (Mazur et al., 2010), and these rocks might have been recycled during the Late Cretaceous.

The North Sudetic Basin, situated on the northern periphery of the Bohemian Massif, was one of a number of Late Cretaceous basins partly filled with coarse-grained quartz-rich sandstones (Fig. 1). The North Sudetic Synclinorium is a post-deformational remnant of this basin. The clastic rocks of the North Sudetic Synclinorium have been interpreted for years as largely derived from the nearby Karkonosze and Strzegom granite massifs (Scupin, 1912-13; Milewicz, 1965, 1997, 1998; Skoček and Valečka, 1983) and, subordinately, from metamorphic rocks (e.g., Biernacka and Józefiak, 2009), i.e. as 


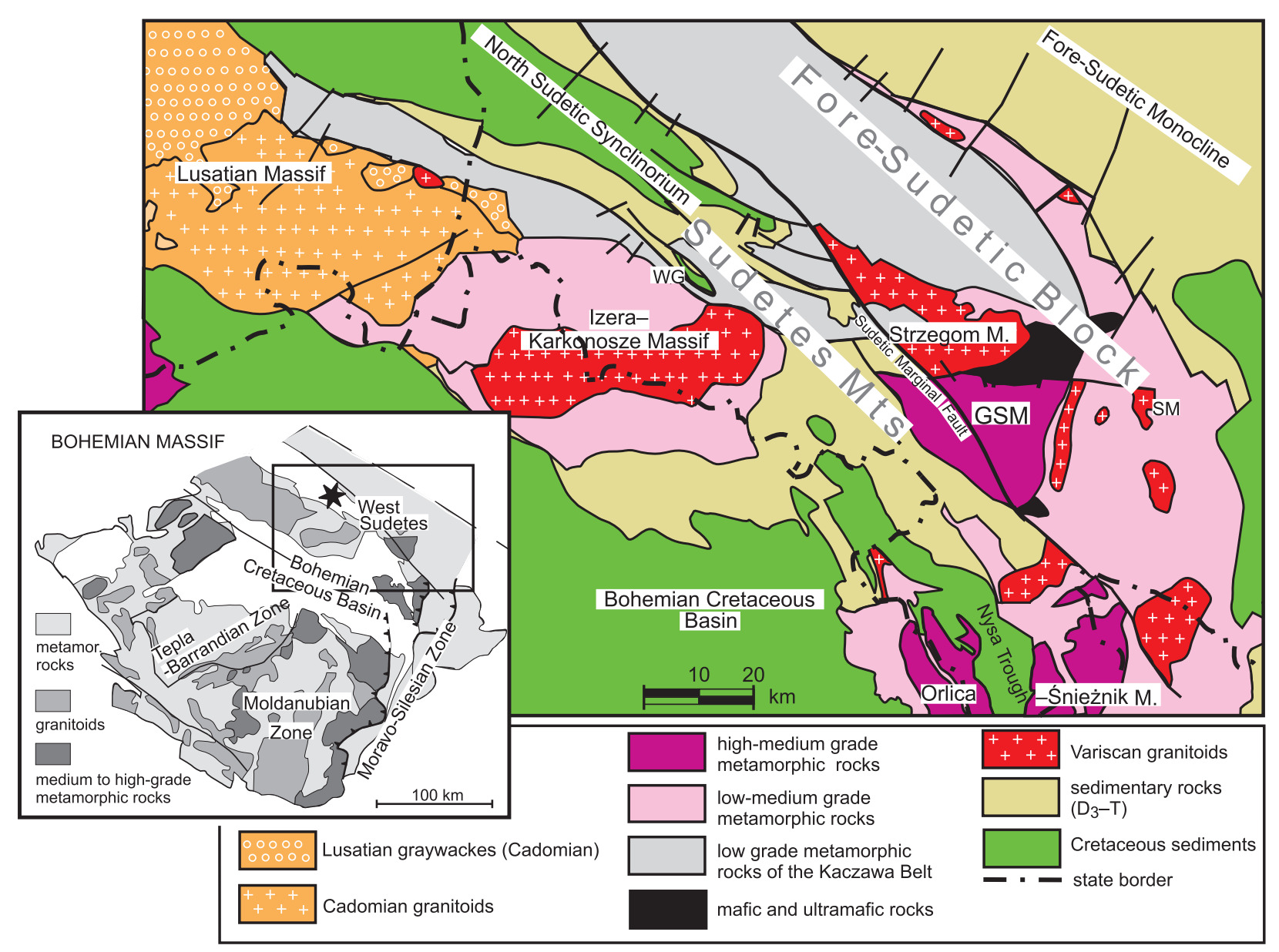

Fig. 1. Location of the North Sudetic Synclinorium within the NE fragment of the Bohemian Massif

Strata younger than Cretaceous are omitted; compiled and modified from Aleksandrowski et al. (1997) and Krenz et al. (2000); inset shows the entire Bohemian Massif (simplified from Dallmeyer et al., 1995); GSM - Góry Sowie Massif, SM - Strzelin Massif, WG - Wleń Graben

first-cycle arenites. Recently, Danišík et al. (2010) evaluated the erosional history of the Karkonosze Massif on the basis of apatite fission track and thermochronological methods, and interpreted rapid erosion since the late Turonian resulting in the removal of as much as $6 \mathrm{~km}$ of overburden in some $15 \mathrm{Myr}$. They suggested either the erosion of the granite itself or of a hypothetical Mesozoic sedimentary cover, but did not find conclusive evidence. The mature quartz-rich composition of sandstones filling the North Sudetic Synclinorium has hindered a more precise determination of their source rocks.

The provenance of quartz arenites is not straightforward to decipher. These sandstones, essentially composed of quartz grains and associated ultrastable heavy minerals, provide limited clues to their origin, so conventional petrographic analyses usually fail to solve this problem (Pettijohn et al., 1987). Various additional methods have been adopted: detailed cathodoluminescence microscopy of quartz grains (e.g., Götte and Richter, 2006), scanning electron microscopy coupled with other methods (Moral Cardona et al., 1997; Bernet et al., 2007), detrital zircon geochronology (e.g., Avigad et al., 2005), and mineral chemistry of tourmaline or rutile (e.g., von Eynatten et al., 2008). In this contribution, the provenance of quartz-rich sandstones from the North Sudetic Synclinorium is constrained on the basis of a combined light and heavy mineral analysis, and particularly a the detrital tourmaline study. The physical features and chemical composition of the detrital tourmaline are compared with those of tourmaline occurring in the presumed source rocks of nearby massifs. The analyses have been conducted for the entire spectrum of Cretaceous siliciclastic deposits filling the North Sudetic Synclinorium, that is for Cenomanian, Turonian, Coniacian, and Santonian sandstones.

Tourmaline is a common accessory mineral in granitoids, metamorphic rocks and clastic sedimentary rocks, and exhibits features useful for provenance studies. Not only does this borosilicate permit numerous ionic substitutions, thus showing a wide variety of possible chemical compositions, but it is also exceptionally resistant to weathering and diagenetic alteration. The classic work of Krynine (1946) already demonstrated that careful observation of tourmaline physical properties, i.e. its diverse colours and forms, might carry valuable provenance information. Further study by Henry and Guidotti (1985) showed that the extensive compositional variability of tourmaline responds to the host environment in which the mineral crystallised and, by inference, was the basis for introducing discrimination diagrams linking the chemical composition of tourmaline to specific source rocks. This method was further devel- 
oped and elaborated in the work of Henry and Dutrow (1992). Since then, tourmaline has become an effective indicator of the provenance of clastic rocks (e.g., Nascimento et al., 2007). Recent reviews emphasise the remarkable stability of tourmaline and its growing potential in petrogenetic studies (Dutrow and Henry, 2011; van Hinsberg et al., 2011b). Tourmaline is not considered currently to be a single mineral, but a supergroup consisting of a dozen species (Henry et al., 2011).

\section{THE NORTH SUDETIC BASIN IN THE LATE CRETACEOUS}

The North Sudetic Basin originated as an intramontane trough at the end of the Variscan orogeny on the northeastern periphery of the Bohemian Massif (Fig. 1). The trough formed within the low-grade metamorphic Kaczawa Belt and was successively filled with upper Carboniferous to Upper Triassic deposits, and after a hiatus with Upper Cretaceous strata. The total thickness of the sedimentary succession amounts to $c a$. 2500 m (Bałazińska and Bossowski, 1979; Milewicz, 1985). As a result of tectonic movements that intensified during the latest Cretaceous and Paleogene, the former basin was deformed into the North Sudetic Synclinorium (Fig. 1), which is composed of a set of subsidiary synclines, grabens and half-grabens (Oberc, 1972; Bałazińska and Bossowski, 1979; Bossowski and Bałazińska, 1982).

The Upper Cretaceous basin-fill consists of an almost complete succession of upper Cenomanian to lower Santonian marls, mudstones, sandstones and limestones (Milewicz, 1997). The stratigraphy is based primarily on thick-walled bivalve shells (inoceramids). Recently, Walaszczyk (in Voigt et $a l ., 2008 b$ ) reinterpreted the range of inoceramids of the North Sudetic Synclinorium and suggested an interval from the mid-enomanian to the mid-Santonian. The Upper Cretaceous lies slightly discordantly on an older substratum, primarily Triassic sedimentary rocks, and reaches some $1100 \mathrm{~m}$ of preserved thickness in the central part of the basin (Bałazińska and Bossowski, 1979). The succession is predominantly composed of marls, with limestone intercalations in the west and sandstone wedges in the east (Milewicz, 1997; Fig. 2D). The Santonian part differs from the underlying succession in the occurrence of mudstones instead of marls; sandstones still occupy the southeastern part of the basin (Fig. 2D).

Since the mid-Cenomanian, the North Sudetic Basin had been inundated by a shelf sea and bordered by emerged fragments of the northeastern Bohemian Massif - the so called Eastern and Western Sudetic Islands (Fig. 2A, B). The size and boundaries of these islands are poorly constrained. In some palaeogeographical reconstructions the North Sudetic Basin is
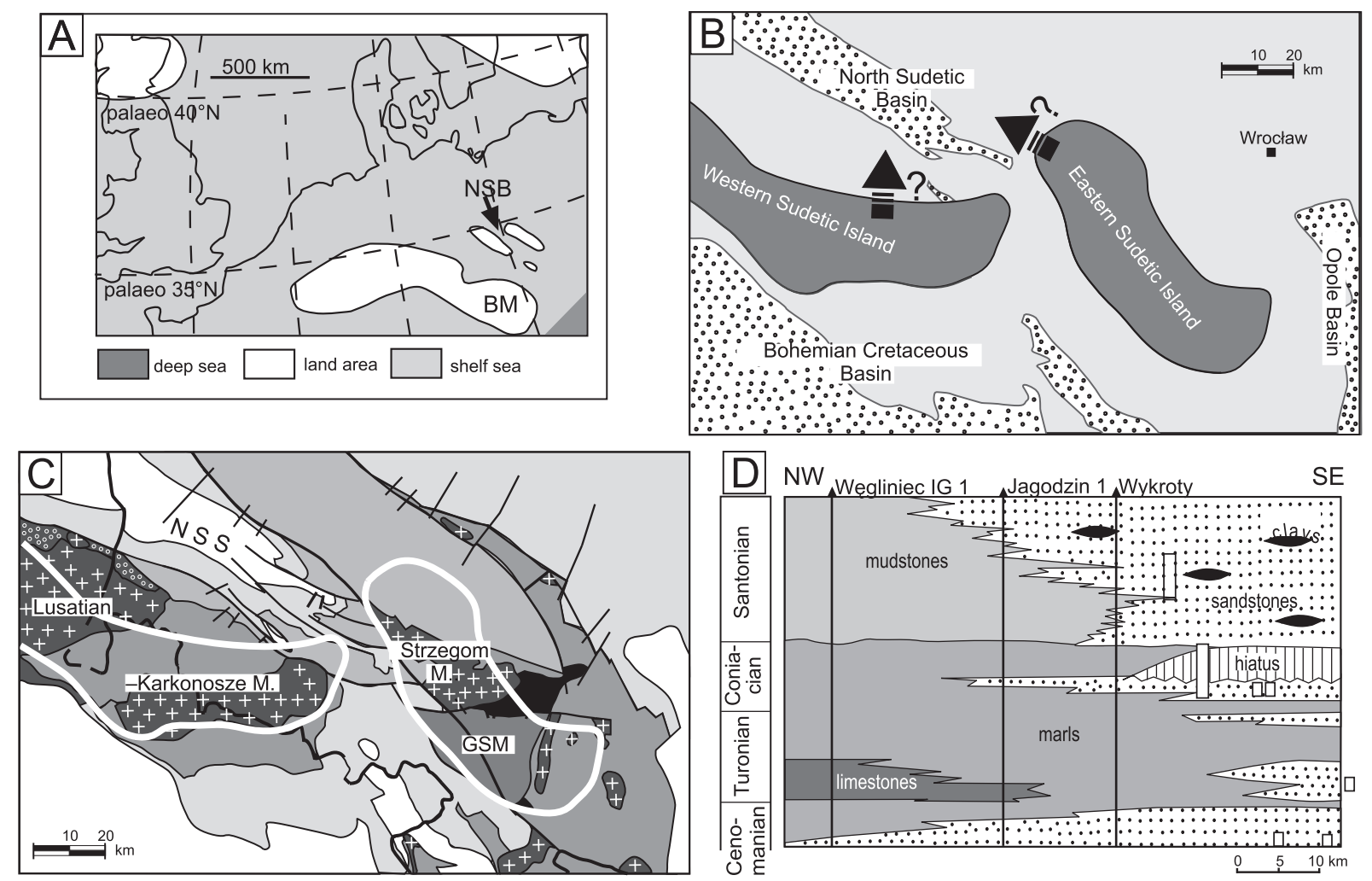

Fig. 2. The North Sudetic Basin in the Late Cretaceous and at present

A - palaeogeography of central-western Europe in the Late Cretaceous, simplified from Ziegler (1990), palaeolatitude based on Hay et al. (1999); B - hypothetical Sudetic Islands in the Turonian according to Jerzykiewicz and Wojewoda (1986), the present-day remnant outcrops of Cretaceous deposits are dotted. Towards the end of the Coniacian and in the Santonian, the islands merged forming a large Sudetic land; C - the extent of the presumed Cretaceous Sudetic Islands against the background of present-day geology (compare Fig. 1); D - cross-section through the North Sudetic Synclinorium (simplified from Milewicz, 1997), vertical lines represent boreholes, rectangles show approximate position of sections studied in this contribution; BM - Bohemian Massif, GSM - Góry Sowie Massif, NSB - North Sudetic Basin, NSS North Sudetic Synclinorium 
depicted as a narrow seaway between the Sudetic Islands, linking a vast Polish-German sea with the sea of the Cretaceous Bohemian Basin (Skoček and Valečka, 1983; Ziegler, 1990; Valečka and Skoček, 1991; Milewicz, 1997; Tröger, 2004). Milewicz $(1965,1997)$ contends that the sea encroached from the north-west and raised its level until the early Turonian peak flooding, as inferred from the widespread occurrence of marls and the formation of limestones in the western part of the basin. Fully marine conditions prevailed during the Turonian and early Coniacian, with some poorly documented relative sea level fluctuations (Milewicz, 1997). Pronounced Late Cretaceous relative sea level fluctuations have been documented for the nearby Bohemian Cretaceous Basin (Uličný et al., 1997, 2009a). The sea started to retreat from the North Sudetic Basin in the mid-late Coniacian; Leszczyński (2010) described a set of transitional marine - terrestrial facies from the eastern part of the basin whereas Milewicz $(1965,1997)$ proposed that during that time the easternmost part was even subjected to denudation. A stepwise appearance of brackish and terrestrial environments in the early (mid) Santonian (Milewicz, 1971, 1988, 1997; Alexandrowicz, 1976; Górniak, 1991) ultimately ended the marine sedimentation. After the early (mid) Santonian, the emerged area of the North Sudetic Basin was subject to erosion (Milewicz, 1965, 1997).

The Upper Cretaceous sandstone wedges of the North Sudetic Synclinorium reach ca. $800 \mathrm{~m}$ in total thickness in its eastern part, thin westwards and pass into basinal fine-grained deposits (Fig. 2D). Coarse siliciclastic material was presumably derived from two sources - the Eastern and Western Sudetic Islands. This hypothesis was postulated by Scupin (1912-13) and was taken for granted for many years subsequently. According to this view (see also Andert, 1934; Skoček and Valečka, 1983; Uličný, 2001), the Western Sudetic Island was identified with the Lusatian and Karkonosze-Izera massifs, whereas the Eastern Sudetic Island corresponded to a central part of the Sudetes and the Fore-Sudetic Block, with the Gorry Sowie Massif as the most characteristic element (Fig. 2C). In general, the two areas differ in their lithological composition and consist primarily of coarse-grained granites in the former and various metamorphic and plutonic rocks in the latter.

\section{MATERIAL AND METHODS}

Thirty-seven samples of Upper Cretaceous sandstones were taken at 7 localities, primarily from active open-pit mines where these sandstones were exploited as building stones, as a raw material for glass industry and as a source of kaolinite, and subordinately from natural exposures or disused quarries. The sampled sandstones were Cenomanian, early to mid-Turonian, Coniacian, and Santonian in age (Fig. 3). Four localities Lwówek Śląski, Jerzmanice, Rakowiczki, and Czerna - have been proposed by Milewicz (1985) as stratotypical of the Upper Cretaceous of the North Sudetic Synclinorium. The age of the sandstones has been ascertained on the basis of casts of inoceramids and the geological context with interfingering marls rich in foraminifera and other fauna (Scupin, 1921-13; Milewicz, 1970, 1988, 1997; Alexandrowicz, 1971, 1976; Teisseyre, 1992) and was not investigated again in this study. Additionally, 3 samples were taken from the uppermost part of the Triassic (Buntsandstein) sandstones which directly underlie the Cenomanian sandstones at the Lwówek Ślaski locality.

The Cenomanian and Turonian sandstones are largely coarse-grained and moderately well to poorly sorted, whereas the Coniacian sandstones are fine- to medium-grained and far better sorted. The Santonian sandstones are medium- to coarse-grained and moderately well/ poorly sorted; they intercalate with thick kaolinite-rich clays and thin coal layers. Sedimentary structures are often obscured by bioturbation, which also worsened the sorting. Fine- and medium-scale cross-stratification was observed only locally.

To ascertain the content of quartz grains 22 thin sections were prepared from selected sandstones (Fig. 3). Heavy mineral analyses were carried out at all 40 samples. Because all the samples were slightly to moderately lithified, gently crushing and rinsing with water preceded sieving at 1 phi intervals from -2 to +4 phi (from 4 to $<0.063 \mathrm{~mm}$ ). Heavy minerals were separated from the 3-4 phi (125 to $63 \mu \mathrm{m})$ fraction using sodium polytungstate aqua solution (specific gravity 2.84 ) and mounted on glass slides with Canada balsam. Heavy mineral frequency data were obtained by ribbon counting of 300 non-opaque non-micaceous grains. Independently, colour tourmaline varieties and morphological types were quantified in each sample based on 100 randomly scattered tourmaline grains.

Tourmaline chemistry was determined on 12 polished thin sections prepared from samples representing each locality (see Fig. 3) with the use of a Cameca $S X-100$ electron microprobe (15 kV accelerating voltage, $10 \mathrm{nA}$ probe current, 1-2 mm beam diameter, $40 \mathrm{~s}$ counting time for each element) at Warsaw University. A ZAF matrix correction routine was utilised. The following standards were used: diopside $(\mathrm{Ca}, \mathrm{Mg}, \mathrm{Si})$, cordierite $(\mathrm{Al}), \mathrm{Fe}_{2} \mathrm{O}_{3}(\mathrm{Fe})$, albite $(\mathrm{Na})$, rutile (Ti), phlogopite $(\mathrm{F})$, rhodonite $(\mathrm{Mn})$, orthoclase $(\mathrm{K}), \mathrm{Cr}_{2} \mathrm{O}_{3}(\mathrm{Cr})$. Chemical composition in one spot per each tourmaline grain was measured in the majority of analyses; in the case of distinct mineral zoning (revealed by optical or back-scattered electron microscopy), two spots per grain were analysed. Approximately 800 tourmaline grains were investigated, plotted on discrimination diagrams and recalculated into crystal-chemical tourmaline formulae, based on the generalised tourmaline formula $\mathrm{XY}_{3} \mathrm{Z}_{6}\left(\mathrm{~T}_{6} \mathrm{O}_{18}\right)\left(\mathrm{BO}_{3}\right)_{3} \mathrm{~V}_{3} \mathrm{~W}$ (Hawthorne and Henry, 1999; Henry et al., 2011), where $\mathrm{X}=\mathrm{Na}^{+}, \mathrm{Ca}^{2+}, \mathrm{K}^{+}$, vacancy; $\mathrm{Y}=$ $\mathrm{Mg}^{2+}, \mathrm{Fe}^{2+}, \mathrm{Mn}^{2+}, \mathrm{Al}^{3+}, \mathrm{Li}^{+}, \mathrm{Fe}^{3+}, \mathrm{Ti}^{4+} ; \mathrm{Z}=\mathrm{Al}^{3+}, \mathrm{Fe}^{3+}, \mathrm{Mg}^{2+}$, $\mathrm{Cr}^{3+} ; \mathrm{T}=\mathrm{Si}^{4+}, \mathrm{Al}^{3+} ; \mathrm{B}=\mathrm{B}^{3+} ; \mathrm{V}=\mathrm{OH}^{-}, \mathrm{O}^{2-} ; \mathrm{W}=\mathrm{OH}^{-}, \mathrm{F}^{-}, \mathrm{O}^{2-}$. Tourmaline formulae were normalised on the basis of 31 anions, assuming all $\mathrm{Fe}$ as $\mathrm{Fe}^{2+}$, the sum of $(\mathrm{OH}+\mathrm{F})$ equal to 4 atoms per formula unit ( $a p f u$ ), and the contents of boron equal to 3 apfu. The partial tourmaline composition data - without direct measurement of $\mathrm{B}, \mathrm{H}, \mathrm{Li}$, and the oxidation state of $\mathrm{Fe}-$ make precise classification impossible, although the assumptions are generally correct (Henry et al., 2011).

Additionally, tourmaline grain morphology was studied in two samples with a Zeiss EVO 40 scanning microscope (17.1 kV voltage) at the Electron Microscopy Department, Poznań University. The grains were hand-picked from the J5 (Turonian) and C2 (Santonian) samples, placed on double-sided adhesive tape and coated with gold. Because the tourmaline grains from both specimens did not differ, the remaining samples were not analysed. 

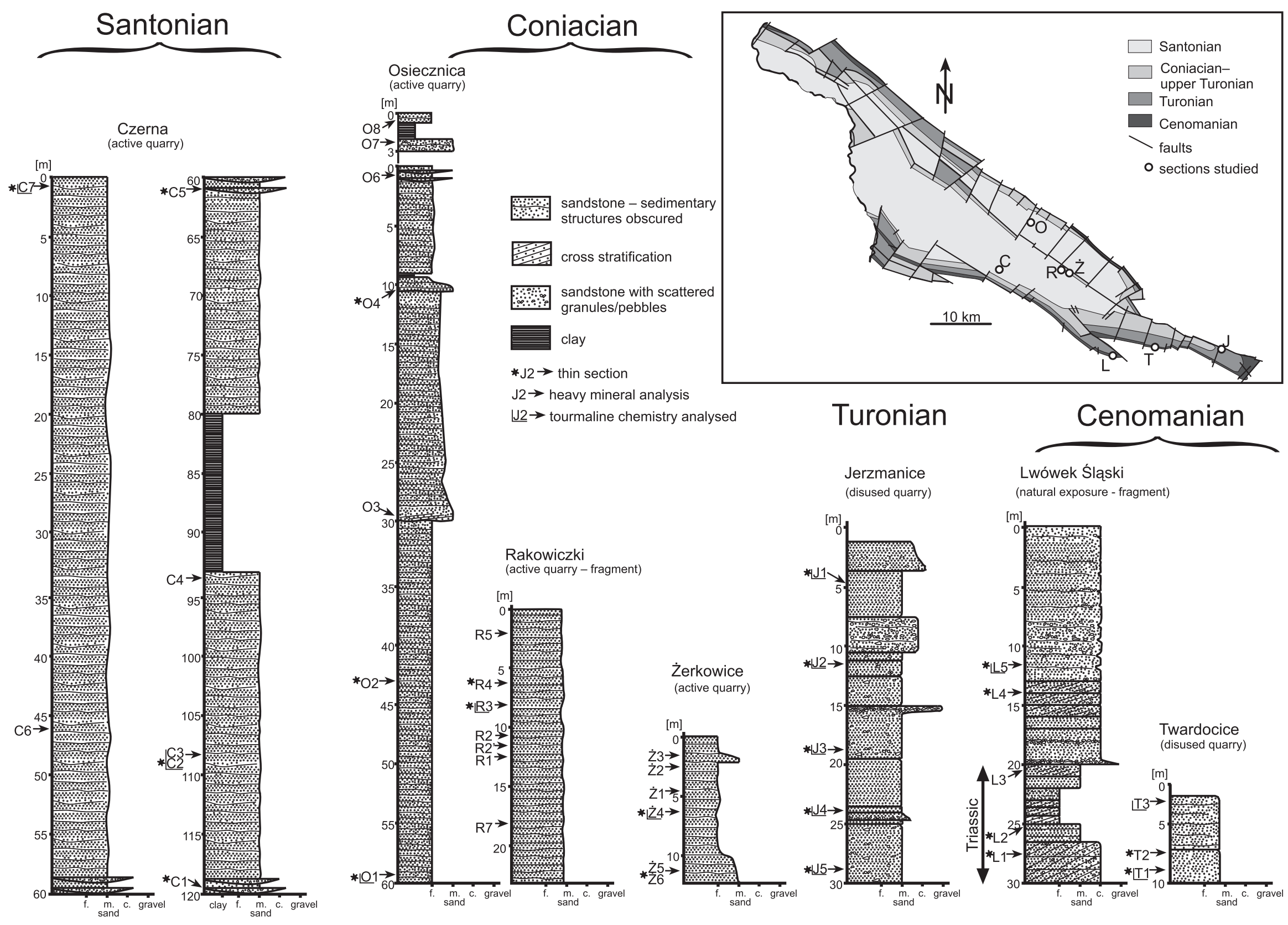

Fig. 3. Measured sections of Upper Cretaceous sandstones from the North Sudetic Synclinorium 


\section{RESULTS}

\section{SANDSTONE PETROGRAPHY}

The majority of sandstones studied plot in the field of quartz arenite in the Pettijohn et al. (1987) classification diagram, containing as much as $99 \%$ quartz grains among the framework components (Fig. 4). Two exceptions were observed: (a) the Turonian sandstones from Jerzmanice show considerably higher alkali feldspar contents and are classified as subarkosic arenites, and (b) some particularly coarse-grained samples contain several percent of lithic fragments that allows classification as sublithic arenites. A significant fraction of the quartz grains occurs in a polycrystalline variety, in the range from $c a .45 \%$ in the coarse- to medium-grained Cenomanian, Turonian and Santonian sandstones to $c a$. $20 \%$ in the fine- to medium-grained Coniacian samples. The remaining quartz grains are monocrystalline; chert fragments are either absent or occur in trace abundances. Part of the monocrystalline quartz is probably volcanic in origin - some coarse grains in the Turonian sandstones show bipyramidal outlines, embayments and lack undulatory extinction. Scarce monocrystalline quartz grains containing abundant sillimanite inclusions were encountered in all speciments. Rare lithic grains are sillimanite- or muscovite-bearing metamorphic rocks, fine-grained clastics, and volcanic rock fragments. In the Santonian sandstones which are relatively rich in lithic grains, fragments of tourmaline-bearing gneiss occur.

A characteristic feature of the Cenomanian, Turonian and Coniacian sandstones is a low degree of grain roundness: grains are either angular or sub-angular to sub-rounded (Fig. 5). By contrast, the Santonian sandstones contain a distinctly higher proportion of well-rounded grains, although none of the samples studied fulfilled the requirements of a texturally mature sandstone (well sorted, well rounded grains). The Cenomanian, Turonian and Santonian sandstones are moderately or even poorly sorted (Fig. 5A). The well sorted Coniacian sandstones (Fig. 5B) contain angular quartz grains (Fig. 5D).

Diagenetically, the Coniacian and Santonian sandstones differ from the underlying Turonian and Cenomanian siliciclastic rocks in the contents of kaolinite associated with small amounts

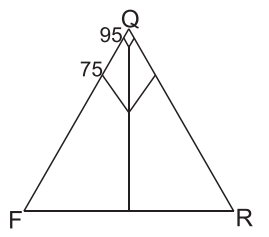

Cretaceous sandstones from the North Sudetic Synclinorium displayed on Pettijohn's et al. (1987) of quartz cement. The amount of kaolinite (3-10 vol\%) is higher in the Santonian samples. Finely crystalline kaolinite replaces grains (Fig. 5F) or partly fills the pore-space and arguably comes from the destruction of less resistant grains. The Turonian and Cenomanian sandstones show instead clay mineral grain-coating. All the sandstones exhibit a high degree of mechanical compaction as indicated by the occurrence of bent flexible lithic fragments and fractured rigid grains (Fig. 5E).

Heavy minerals are common in the sandstones studied; their content in the 3-4 phi sandstone fraction varies between 0.1 and 3.5 wt. $\%$. One-third of the samples contains $>1.0 \mathrm{wt} . \%$ of heavy minerals (Fig. 6). The composition of the heavy fraction in all but the Turonian samples is monotonous and dominated by the assemblage of zircon, tourmaline and rutile. The ZTR maturity index (sum of the percentage of zircon, tourmaline and rutile - Hubert, 1962) surpasses $75 \%$ in all the Cenomanian, Coniacian and Santonian samples. The highest ZTR values (90-97\%) are characteristic of the Coniacian and Santonian sandstones. The remaining translucent heavy minerals are anatase, staurolite, kyanite, sillimanite and monazite. The latter four minerals frequently show signs of dissolution, in the form of honeycomb texture or dissolution pits. The Turonian heavy mineral assemblages stand out against this background and differ primarily in possessing abundant garnet. Besides, the Cenomanian, Turonian and Coniacian sandstones contain minor amounts of staurolite, sillimanite and kyanite (Fig. 6). This is in marked contrast to the underlying Triassic sandstones and the overlying Santonian siliciclastic rocks, which are composed exclusively of quartz and ultrastable minerals (zircon, tourmaline, rutile and anatase).

Among the predominating zircon, tourmaline and rutile, tourmaline is by far the most abundant mineral and thus particularly suitable for further research.

\section{DETRITAL TOURMALINE}

PHYSICAL PROPERTIES

The most striking feature of all the tourmaline populations studied is the overwhelming predominance of angular grains (63-99\%; Fig. 7). Grains which show at least one rounded or sub-rounded surface, or several distinctly euhedral surfaces, were classified as "rounded", "sub-rounded" or "euhedral", assuming that they constitute broken fragments of larger grains. Utterly rounded, sub-rounded and euhedral tourmalines also occur within the populations studied (Fig. 8A-L). Taking into consideration the non-angular grains, the following trends were observed:

- the content of rounded and sub-rounded tourmaline grains is higher in the Coniacian and Santonian sandstones (av. 13\% of the tourmaline population and as high as $30 \%$ in sample O8) compared to the Cenomanian and Turonian samples (av. 4\%);

- the frequency of euhedral tourmaline grains in the Santonian samples (av. 4\%) is slightly lower in relation to other samples (av. 7\%).

SEM observations revealed smooth grain surfaces, some sharp-edged, without traces of dissolution (Fig. 7). 

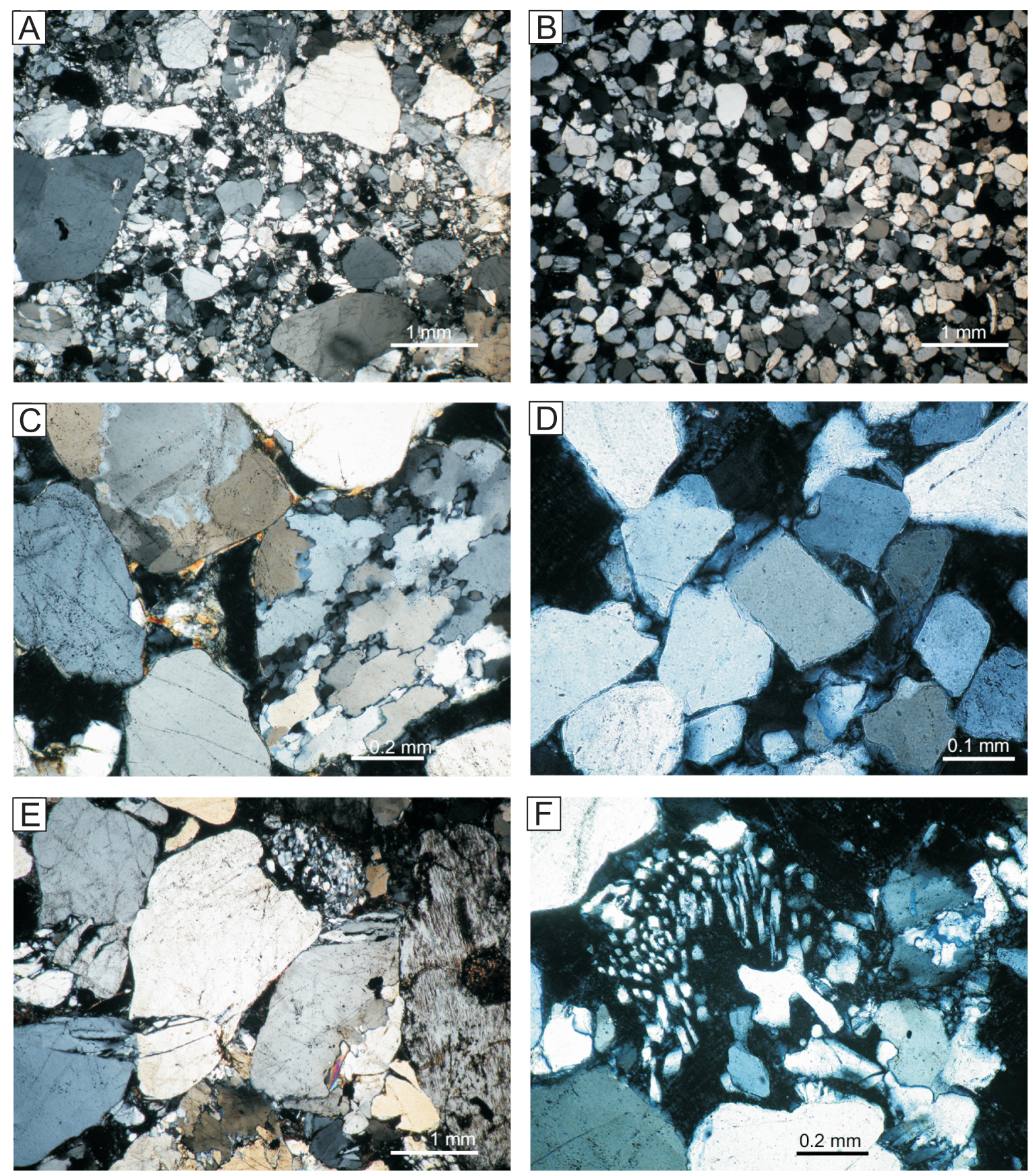

Fig. 5. Photomicrographs of Upper Cretaceous sandstones from the North Sudetic Synclinorium

A - poorly sorted Cenomanian sandstone (sample T2); B - well-sorted fine-grained Coniacian sandstone (sample Z6); C - sub-angular poly- and monocrystalline quartz grains in Cenomanian sandstone (sample L4); D - angular quartz grains (sample O1); $\mathbf{E}$ - fractured grains in compacted Turonian sandstone (sample J5); $\mathbf{F}$ - partly kaolinitised grain with quartz-feldspar intergrowth (granophyric texture); finely crystalline kaolinite seems almost isotropic under crossed polars (sample C2)

Six tourmaline colour varieties were distinguished by optical microscopy (Fig. 8A-L): 1 - brown (various tints), 2 green, 3 - colourless (to pale yellow), 4 - blue (or violet), 5 pink to black (or dark green), 6 - two-colour (brown-green or brown-bluish). Frequently, fragments of larger tourmaline crystals were observed perpendicular to their $z$ axis, therefore the full range of pleochroic colours was invisible and the tourmaline grains were characterized by one dominant colour. A distinct seventh variety was defined on the basis of numerous fibrous inclusions of sillimanite. This type is brown in colour although rare green grains were also noticed. The most prominent observation is that all the colour varieties occur in all the sandstones studied in approximately similar ratios, with only subtle differences (Fig. 8). The brown variety apparently predominates in the tourmaline populations $(>80 \%)$. Green tourmaline is also common although it rarely exceeds $10 \%$. The two-colour variety, usually with bluish cores and brown rims, amounts to some $2-4 \%$. The colourless and black types consti- 

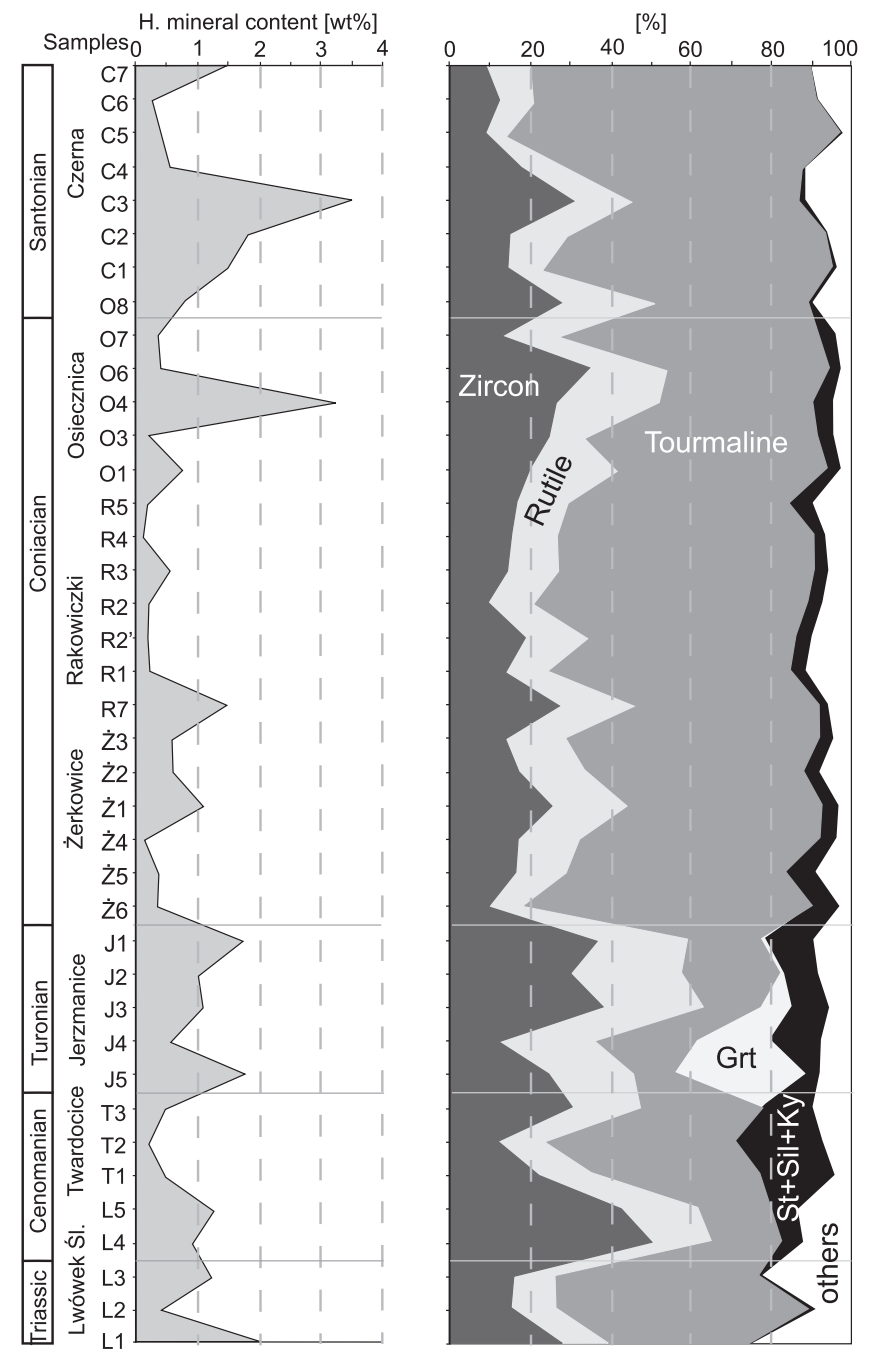

Fig. 6. Heavy mineral content [wt $\%$ ] in the 3-4 phi sandstone fraction and the diversity of translucent heavy minerals

Grt - garnet; St+Sil+Ky - staurolite + sillimanite + kyanite; others - anatase + minor monazite

tute $1-3 \%$ of the tourmaline spectrum. The rarest variety is the blue one $(<1 \%)$, most often occurring in the form of ideally rounded grains (Fig. 8F).

The Turonian sandstones slightly differ from the remaining samples in the higher frequencies of brown and colourless tourmaline accompanied by the slightly lower quantities of other types. The Coniacian sandstones, particularly those from the Żerkowice quarry, show higher contents of green tourmaline compared to the other samples. Pink-to-black (dark green) tourmaline predominantly occurs in the Turonian and Coniacian sandstones.

Interestingly, the Triassic tourmaline population does not significantly differ from the Cretaceous specimens. Their characteristic feature is a relatively high percentage of rounded grains (up to 21\%) and of tourmaline with sillimanite inclusions $(>10 \%)$.

\section{MINERAL CHEMISTRY}

The tourmaline populations - from Cenomanian to Santonian - show a similar diversity of chemical composition

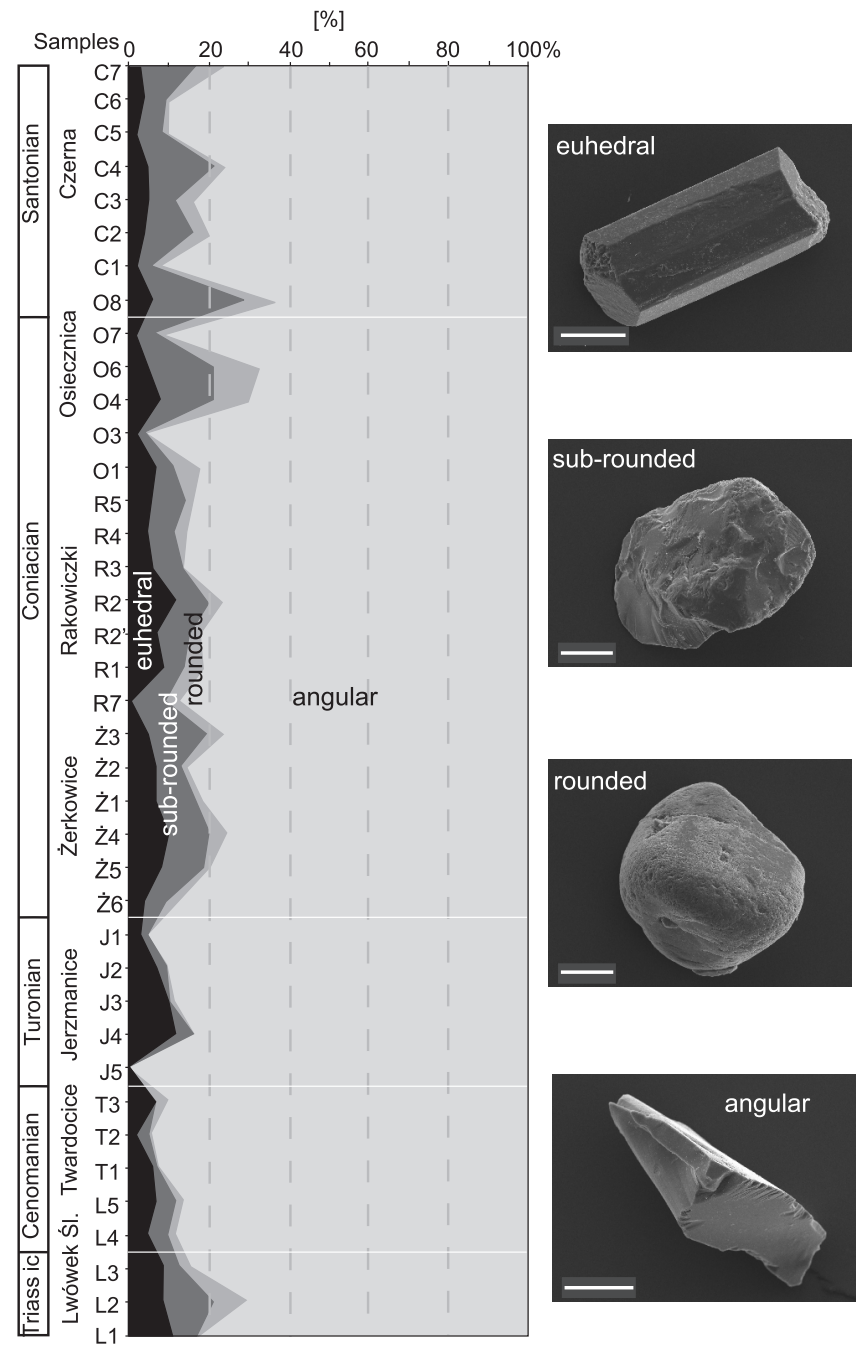

Fig. 7. Quantitative diversity of detrital tourmaline shape in Upper Cretaceous sandstones from the North Sudetic Synclinorium

SEM photomicrographs of various tourmaline shapes are included; scale bars $-50 \mu \mathrm{m}$

(Fig. 9). In terms of X-site occupancy, most tourmalines belong to the alkali group, although a major part of them exhibits significant vacancies ( $\sim 30-40 \%$ of the $\mathrm{X}$ site). The majority of grains are F-poor and have Al-rich dravitic-schorlitic composition. The high Al content suggests either an olenite component in the detrital tourmaline or the presence of oxy-tourmaline species (oxy-dravite, oxy-schorl). Although the $\mathrm{Fe} /(\mathrm{Fe}+\mathrm{Mg}$ ) ratios vary in a wide range (0.02-0.99), in most grains $\mathrm{Mg}^{2+}$ prevails over $\mathrm{Fe}^{2+}$ at the Y-site; thus dravite unambiguously prevails over schorl (Table 1). The populations studied are also akin in terms of Ti, Mn, and Cr content (Fig. 10). All these elements occur in low concentrations, typically around 0.1 apfu for $\mathrm{Ti},<0.05$ for $\mathrm{Mn},<0.01$ for $\mathrm{Cr}$ (with one exceptional grain: $\mathrm{Cr}=0.47 \mathrm{apfu}$ ). A minor subgroup (2-6\%) in all the tourmaline populations belongs to the X-vacant group. Generally, foitite is more common than magnesio-foitite, although both species are present.

However, as in the case of tourmaline physical properties, subtle differences can be discerned between the populations studied. The most distinct difference is the occurrence of calcic group tourmalines in the Turonian samples $(2 \%$ of the population; they occur in the upper part of the Turonian section). Be- 


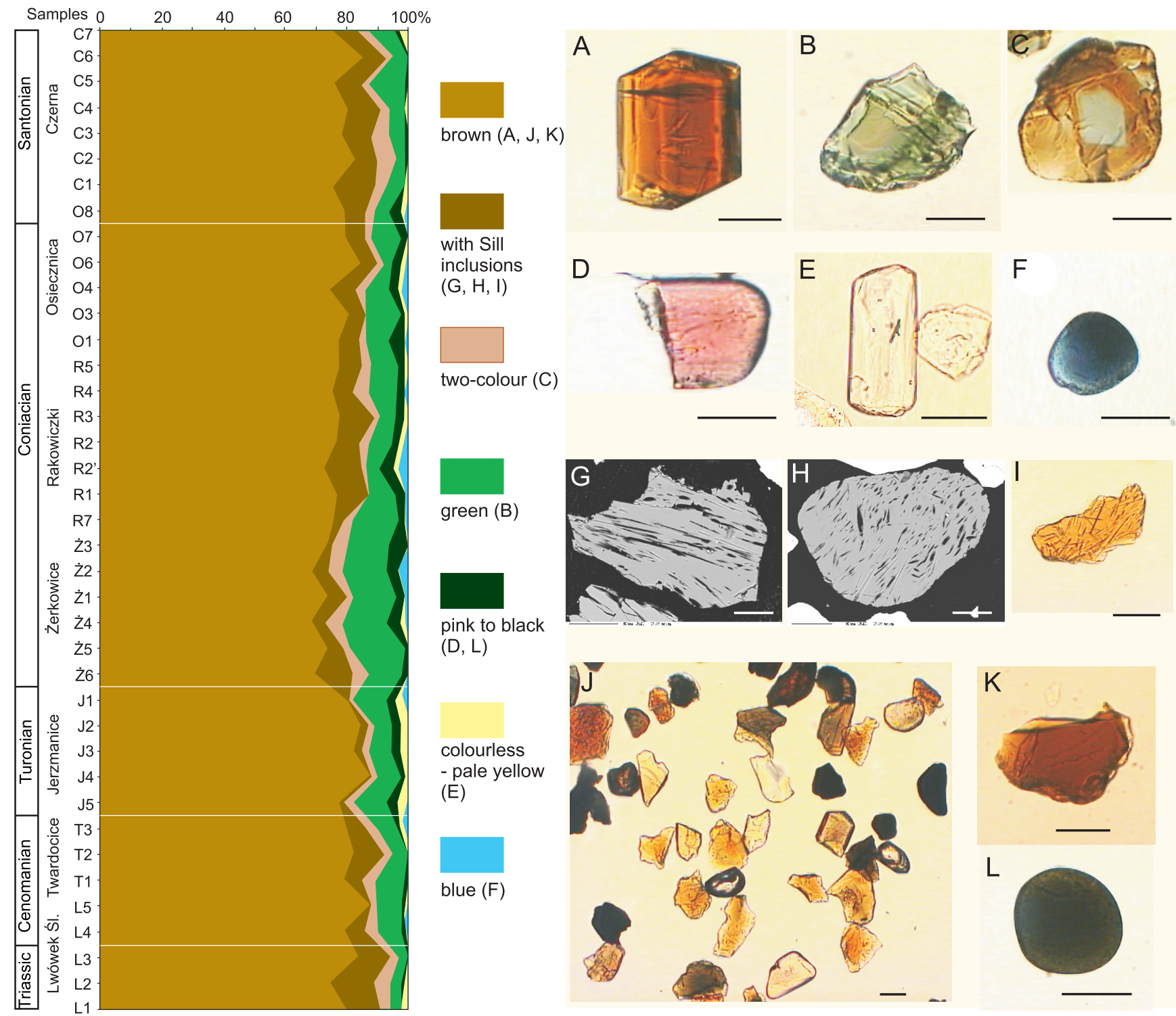

Fig. 8. Quantitative diversity of tourmaline colour varieties in Upper Cretaceous sandstones from the North Sudetic Synclinorium

A-F and $\mathbf{I}-\mathbf{L}$ - photomicrographs of tourmaline grains; $\mathbf{G}-\mathbf{H}$ - back scattered electron images; scale bars - 50 $\mu \mathrm{m}$

cause $\mathrm{Mg}^{2+}$ prevails over $\mathrm{Fe}^{2+}$ at the $\mathrm{Y}$-site, this tourmaline can be classified as uvite. Only the Turonian population contains a minor group of F-rich dravite-schorl $(0.2<\mathrm{F}<0.4$ apfu $)$. Moreover, the Turonian and Coniacian populations, unlike the remaining two, contain approx. $10 \%$ of Ca-enriched dravite $(0.4>\mathrm{Ca} \geq 0.2$ apfu $)$ and a few grains $(\sim 1 \%)$ of pure dravite $[\mathrm{Fe} /(\mathrm{Fe}+\mathrm{Mg})<0.04]$. In turn, the Santonian population shows a slightly higher percentage of foitite $(6 \%)$ and schorl $(35 \%)$ in comparison to the remaining specimens.

In the Henry and Guidotti (1985) discrimination diagrams the majority of the detrital tourmalines plot in the field of Al-rich, Ca-poor metapelites and metapsammites, and, to a lesser extent, occupy the field of granitoids and pegmatites - predominantly in its part adjacent to the metapelites (Fig. 9). A portion of grains from each sample shows such a high $\mathrm{Al}$ content that it falls in the compositional gap field of the diagram. Other chemical varieties, i.e. those characteristic of Al-poor metapelites and metapsam- mites, calc-silicate rocks, ultramafics and metacarbonates, occur in minor quantities or accessorily (Fig. 9).

No clear-cut relationship between tourmaline colour and chemical composition was found, corroborating the observation that tourmaline colour depends on many factors (e.g., Henry and Dutrow, 1992). The predominant brown and green varieties could be either magnesium- or iron-rich. Dravite, schorl, foitite and uvite show various colours. On the other hand, the rare tourmaline colour types often exhibit peculiar chemistry:

- the colourless (to pale yellow) tourmaline is rich in $\mathrm{Mg}$ and poor in $\mathrm{Fe}$ (rare colourless tourmaline is either pure dravite or dravite-uvite solid solution; some uvite grains are also colourless);

- in contrast, the distinctly blue (or violet) grains most often are of schorl composition, light blue varieties have also dravite or foitite composition;

- most dark green grains show lower amounts of $\mathrm{Al}$ and elevated $\mathrm{Ca}$ concentrations. 

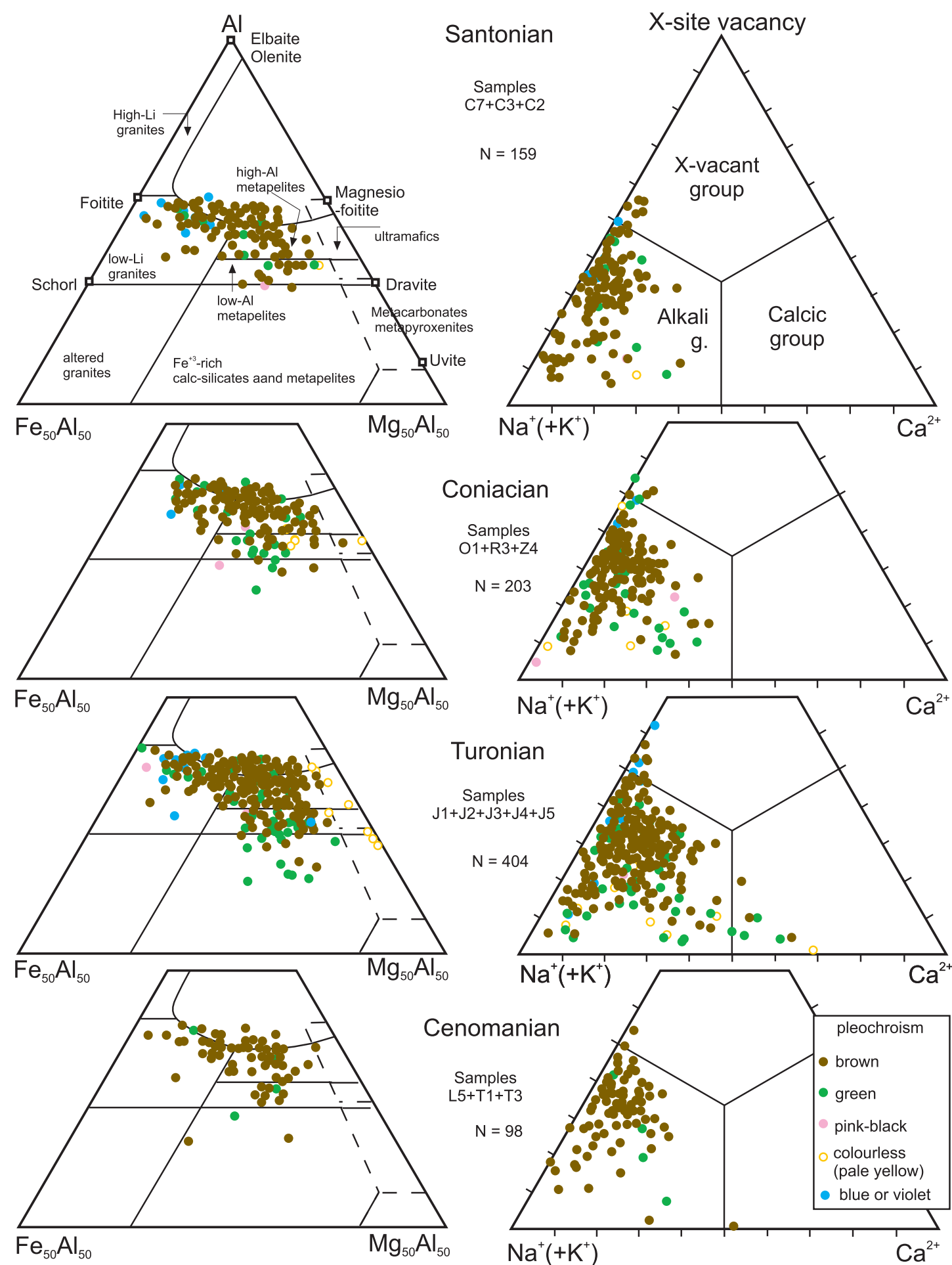

Fig. 9. Composition of detrital tourmaline from Upper Cretaceous sandstones, North Sudetic Synclinorium, plotted in $\mathrm{Fe}_{(\text {tot })}-\mathrm{Mg}-\mathrm{Al}$ and $(\mathrm{Na}+\mathrm{K})-\mathrm{Ca}-\mathrm{vacancy}$ diagrams (after Henry and Guidotti, 1985; Henry et al., 2011)

\section{TOURMALINE IN SUDETIC CRYSTALLINE ROCKS}

Tourmaline is a ubiquitous accessory mineral in various igneous, metamorphic and sedimentary rocks of the Sudetic area (see Lis and Sylwestrzak, 1986 for a review). However, two regions are particularly rich in this mineral: (a) the marginal part of the Karkonosze Pluton granite and its metamorphic envelope, where tourmaline abounds in greisens, metasomatites, pegmatites, aplites, granite-gneisses, gneisses and mica schists (Karwowski, 1973; Kozłowski, 1974; Pieczka, 1996, Słaby and Kozłowski, 2005), and (b) the Góry Sowie Massif and its vicinity, where tourmaline occurs commonly in pegmatites and 
Representative chemical analyses of detrital tourmaline

\begin{tabular}{|c|c|c|c|c|c|c|c|c|c|c|c|c|}
\hline Grain & O1_2 & O1_17 & O1_8 & C7_14 & R3_17 & L5_4 & L5_29 & Z4_22 & $\mathrm{J} 2 \_7$ & J2_8 & J2_98 & J5_37 \\
\hline $\mathrm{SiO}_{2}$ & 36.31 & 36.77 & 36.39 & 36.60 & 35.80 & 36.26 & 36.27 & 36.69 & 35.78 & 36.44 & 37.28 & 38.74 \\
\hline $\mathrm{TiO}_{2}$ & 0.77 & 1.17 & 1.90 & 0.68 & 0.10 & 0.92 & 0.91 & 0.97 & 2.39 & 0.93 & 0.25 & 0.42 \\
\hline $\mathrm{Al}_{2} \mathrm{O}_{3}$ & 33.56 & 31.51 & 32.19 & 35.13 & 34.77 & 33.79 & 34.27 & 33.76 & 31.27 & 33.87 & 35.40 & 32.62 \\
\hline $\mathrm{Cr}_{2} \mathrm{O}_{3}$ & 0.00 & 0.09 & 0.09 & 0.02 & 0.09 & 0.00 & 0.38 & 0.07 & 0.04 & 0.02 & 0.00 & 0.18 \\
\hline $\mathrm{FeO}$ & 8.54 & 5.01 & 7.24 & 6.67 & 11.72 & 5.50 & 6.40 & 6.99 & 8.87 & 6.91 & 6.14 & 0.64 \\
\hline $\mathrm{MgO}$ & 4.25 & 7.84 & 5.67 & 5.24 & 1.79 & 6.72 & 5.34 & 5.35 & 5.55 & 5.97 & 5.08 & 10.76 \\
\hline $\mathrm{CaO}$ & 0.32 & 0.96 & 0.40 & 0.26 & 0.12 & 0.58 & 0.33 & 0.52 & 1.19 & 0.34 & 0.30 & 0.26 \\
\hline $\mathrm{MnO}$ & 0.07 & 0.11 & 0.05 & 0.01 & 0.14 & 0.00 & 0.00 & 0.04 & 0.01 & 0.02 & 0.07 & 0.00 \\
\hline $\mathrm{Na}_{2} \mathrm{O}$ & 1.75 & 2.09 & 1.98 & 1.90 & 1.56 & 1.94 & 1.71 & 1.90 & 1.49 & 1.92 & 1.49 & 2.95 \\
\hline $\mathrm{K}_{2} \mathrm{O}$ & 0.00 & 0.00 & 0.02 & 0.01 & 0.01 & 0.04 & 0.04 & 0.04 & 0.03 & 0.00 & 0.00 & 0.00 \\
\hline $\mathrm{F}$ & 0.02 & 0.04 & 0.01 & 0.16 & 0.06 & 0.08 & 0.02 & 0.05 & 0.12 & 0.02 & 0.03 & 0.03 \\
\hline $\mathrm{B}_{2} \mathrm{O}_{3} *$ & 10.60 & 10.71 & 10.67 & 10.83 & 10.51 & 10.74 & 10.71 & 10.77 & 10.56 & 10.72 & 10.79 & 11.04 \\
\hline Total & 96.19 & 96.30 & 96.61 & 97.51 & 96.66 & 96.57 & 96.37 & 97.15 & 97.30 & 97.16 & 96.82 & 97.63 \\
\hline $\mathrm{O}=\mathrm{F}$ & -0.01 & -0.02 & -0.00 & -0.07 & -0.03 & -0.03 & -0.01 & -0.02 & -0.05 & -0.01 & -0.01 & -0.01 \\
\hline Total & 96.18 & 96.28 & 96.61 & 97.44 & 96.63 & 96.54 & 96.36 & 97.13 & 97.25 & 97.15 & 96.81 & 97.62 \\
\hline \multicolumn{13}{|c|}{ Numbers of ions based on $31(\mathrm{O}, \mathrm{H}, \mathrm{F}, \mathrm{Cl})$} \\
\hline $\mathrm{Si}$ & 5.953 & 5.969 & 5.927 & 5.875 & 5.920 & 5.865 & 5.883 & 5.922 & 5.886 & 5.909 & 6.007 & 6.096 \\
\hline $\mathrm{Ti}$ & 0.095 & 0.143 & 0.233 & 0.082 & 0.012 & 0.112 & 0.111 & 0.118 & 0.296 & 0.113 & 0.030 & 0.049 \\
\hline $\mathrm{Cr}$ & 0.000 & 0.012 & 0.012 & 0.003 & 0.011 & 0.000 & 0.048 & 0.009 & 0.005 & 0.003 & 0.000 & 0.022 \\
\hline $\mathrm{Al}$ & 6.484 & 6.029 & 6.179 & 6.646 & 6.778 & 6.443 & 6.551 & 6.422 & 6.063 & 6.472 & 6.724 & 6.050 \\
\hline $\mathrm{Fe}^{2+}$ & 1.171 & 0.680 & 0.986 & 0.895 & 1.622 & 0.745 & 0.869 & 0.944 & 1.220 & 0.937 & 0.827 & 0.084 \\
\hline $\mathrm{Mg}$ & 1.039 & 1.897 & 1.377 & 1.254 & 0.440 & 1.620 & 1.292 & 1.287 & 1.361 & 1.443 & 1.220 & 2.523 \\
\hline $\mathrm{Mn}$ & 0.010 & 0.015 & 0.007 & 0.001 & 0.020 & 0.000 & 0.000 & 0.005 & 0.001 & 0.003 & 0.009 & 0.000 \\
\hline $\mathrm{Ca}$ & 0.056 & 0.167 & 0.070 & 0.045 & 0.021 & 0.100 & 0.058 & 0.090 & 0.210 & 0.059 & 0.052 & 0.044 \\
\hline $\mathrm{Na}$ & 0.556 & 0.658 & 0.625 & 0.591 & 0.500 & 0.608 & 0.536 & 0.595 & 0.475 & 0.604 & 0.465 & 0.901 \\
\hline $\mathrm{K}$ & 0.000 & 0.000 & 0.004 & 0.002 & 0.003 & 0.008 & 0.009 & 0.008 & 0.006 & 0.000 & 0.000 & 0.000 \\
\hline B & 3.000 & 3.000 & 3.000 & 3.000 & 3.000 & 3.000 & 3.000 & 3.000 & 3.000 & 3.000 & 3.000 & 3.000 \\
\hline $\mathrm{F}$ & 0.010 & 0.021 & 0.005 & 0.081 & 0.031 & 0.040 & 0.010 & 0.026 & 0.062 & 0.010 & 0.013 & 0.015 \\
\hline $\mathbf{X}_{\mathrm{Mg}}$ & 0.470 & 0.736 & 0.583 & 0.583 & 0.214 & 0.685 & 0.598 & 0.577 & 0.527 & 0.606 & 0.596 & 0.968 \\
\hline $\mathrm{X}$ site vacancy & 0.388 & 0.175 & 0.301 & 0.362 & 0.477 & 0.283 & 0.397 & 0.307 & 0.309 & 0.337 & 0.482 & 0.055 \\
\hline Mineral name & Schorl & Dravite & Dravite & Dravite & Schorl & Dravite & Dravite & Dravite & Dravite & Dravite & Mg-Foitite & Dravite \\
\hline
\end{tabular}

* calculated on the basis of stoichiometry $(\mathrm{B}=3$ apfu $)$

veins accompanying paragneisses, migmatites, amphibolites, granulites and serpentinites (Kryza, 1977; Pieczka, 1996; Pieczka, 2000). The Strzegom-Sobótka Pluton granite, situated nearby the Góry Sowie Massif, also contains tourmaline-bearing pegmatites (Janeczek, 1985; Pieczka and Kraczka, 1988). Thus, assuming that crystalline rocks were exposed at the surface in the Late Cretaceous, the two presumable Sudetic Islands might have delivered tourmaline grains in large quantities. The monograph by Pieczka (1996), pertinent to Polish tourmaline, yields additional information about the remaining Sudetic areas. Pieczka (1996) suggested that tourmaline crystals from various geological regions of Poland carry such peculiar crystal-chemical characteristics that, in the case of an unknown source, it is feasible to recognize it. Moreover, tourmaline from the Karkonosze-Izera Massif and tourmaline from the Góry Sowie Massif differ significantly.

Tourmaline crystals coming from the Karkonosze-Izera Massif most often show orange-yellow or orange-brownish pleochroism (Karwowski, 1973; Kozłowski, 1974; Słaby and Kozłowski, 2005). Furthermore, tourmaline grains either have characteristic grayish-blue rims on orange cores or show patchy distribution of the two colours in one crystal (Słaby and Kozłowski, 2005). Green and blue pleochroic varieties have been also described (Karwowski, 1973; Kozłowski, 1974; Lis and Sylwestrzak, 1986; Pieczka, 1996). The chemical composition of Karkonosze-Izera tourmaline corresponds most often to $\mathrm{Mg}$-poor schorl characteristic of Li-poor granites and pegmatites (Pieczka, 1996). Słaby and Kozłowski (2005) investigated metamorphic rocks surrounding the Karkonosze Pluton and found additionally that such composition is typical of the outer part of tourmalines whereas their cores are composed of Fe-poor dravite corresponding to Al-poor metapelites and metapsammites (Fig. 11). The Karkonosze-Izera tourmaline shows elevated contents of F, and is F-rich at places (Pieczka, 1996; Słaby and Kozłowski, 2005). 

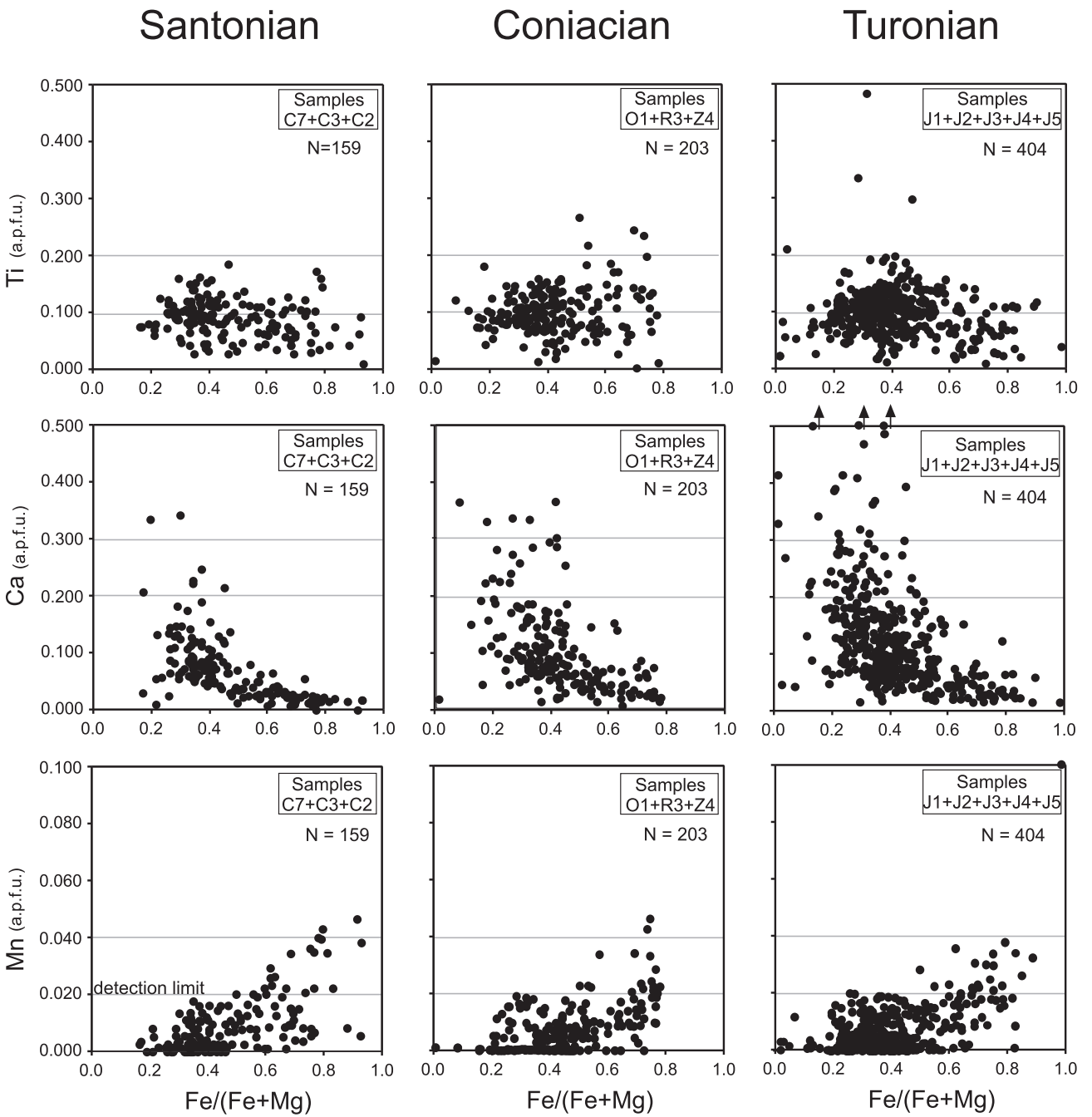

\section{Cenomanian}
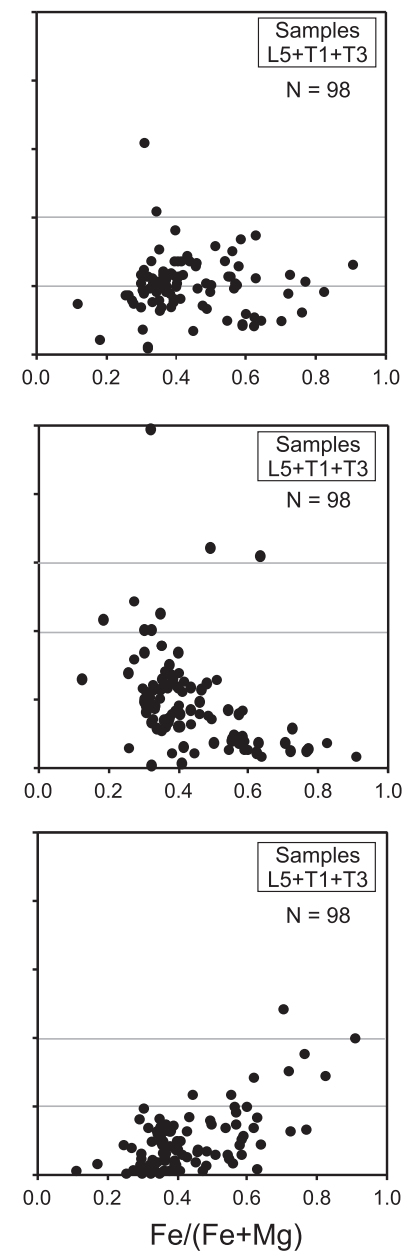

Fig. 10. The content of $\mathrm{Ti}, \mathrm{Ca}$ and $\mathrm{Mn}$ versus $\mathrm{Fe} /(\mathrm{Fe}+\mathrm{Mg})$ in detrital tourmaline grains from successive Upper $\mathrm{Cretaceous}$ sandstones, North Sudetic Synclinorium

Tourmaline crystals from the Góry Sowie Massif usually exhibit distinct pleochroism in brown, yellow, bluish or green colours; zoning is typical (Pieczka, 1996). Varieties occurring in serpentinites are often green or blue in colour (Pieczka and Kraczka, 1996; Pieczka et al., 1996; Sachanbiński et al., 2000). Góry Sowie tourmalines are Al-rich dravite/schorl in composition, occupying the field near the border of the two species (Fig. 11; Pieczka, 1996). Their Al-rich chemical composition is consistent with the Al-rich host environment, as indicated by the occurrence of sillimanite, kyanite and garnet (Kryza, 1977, 1981). The Góry Sowie tourmaline is F-poor (Pieczka, 1996).

In comparison to tourmalines from the Góry Sowie Massif, those from the Strzelin Massif (Fore-Sudetic Block) and from the Orlica-Śnieżnik Massif are distinctly impoverished in Al and enriched in Ca (Fig. 11; Pieczka, 1996). They show characteristic black/dark green - light brown/pink pleochroism. Although uvite has not yet been recognized, calc-silicate rocks or marbles of these geological units may carry some small crystals of calcic-group tourmaline. In turn, tourmaline from the Strzegom Massif granite is similar to that from the Karkonosze-Izera Massif, i.e. Mg-poor schorl with elevated F contents (Fig. 11; Janeczek, 1985; Pieczka, 1996).
A characteristic feature of Sudetic tourmaline is that the mineral is often cracked, with cracks filled with quartz or white mica (e.g., Pieczka, 1996; Słaby and Kozłowski, 2005).

\section{DISCUSSION}

\section{PARENT ROCKS OF THE DETRITAL TOURMALINE}

The diverse composition of the tourmaline grains indicates a number of different parent rocks. Undoubtedly, the most abundant F-poor, Al-rich dravitic tourmaline points to metamorphic rocks $\left(\mathrm{Al}_{2} \mathrm{SiO}_{5}\right.$-bearing metapelites). Although the less abundant F-poor, Al, Mg-rich schorl plot in the field of Li-poor granite in the discrimination diagram of Henry and Guidotti (1985; Fig. 9), it is probably also derived from metamorphic rocks. This tourmaline shows significant X-site vacancy, whereas Mg-rich schorl coming from intermediate igneous rocks usually has Na-rich composition (van Hinsberg et al., 2011a) or is enriched in Ca (Novák et al., 2011). More importantly, this is the composition of the Góry Sowie tourmaline, which formed in abyssal pegmatites in the gneiss/migmatite 


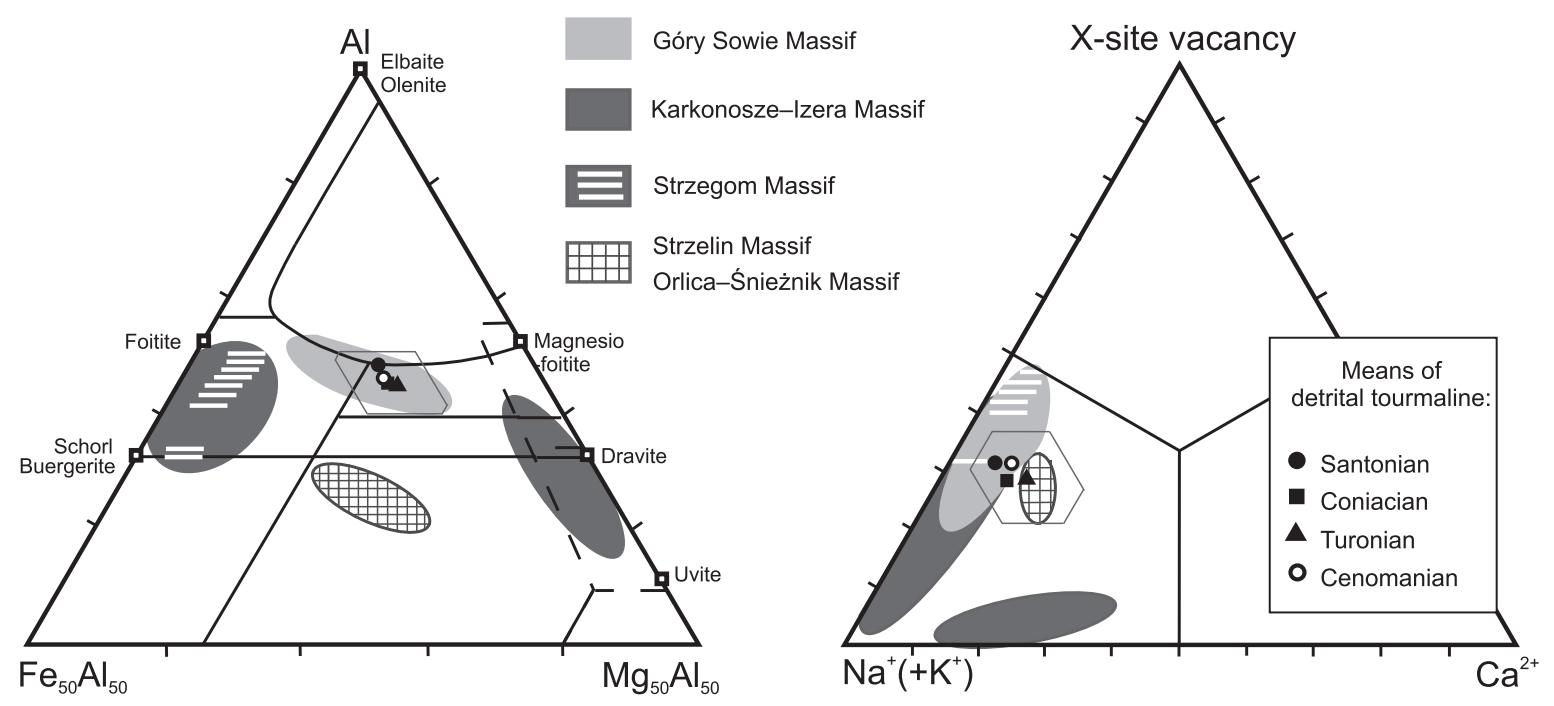

Fig. 11. Typical compositions of tourmaline from selected Sudetic geological units (data from Janeczek, 1985; Pieczka and Kraczka, 1988; Pieczka, 1996, 2000; Słaby and Kozlowski, 2005)

The means of successive detrital tourmaline populations are also plotted;

hexagon shows the range of the standard deviation of the largest Turonian data set

complex. In addition to the predominant metamorphic tourmaline (group 1 and 2), four minor groups can be distinguished in the order of abundance: (3) tourmaline of medium $\mathrm{Al}$ content typical of metapelites devoid of $\mathrm{Al}_{2} \mathrm{SiO}_{5}$, (4) Ca-rich tourmaline derived presumably from calc-silicate rocks and marbles, (5) Fe-rich schorl characteristic of granites, and (6) dravite arguably coming from weathered ultramafic rocks. The occurrence of granitic tourmaline is remarkably rare. The most abundant tourmaline in granitic pegmatites from the Bohemian Massif is Fe-rich schorl or oxy-schorl (Pieczka, 1996; Povondra et al., 1998; Novák et al., 2004; Słaby and Kozłowski, 2005; Burianek and Novák, 2007; Novák and Cempírek, 2010), which is not characteristic of the detrital tourmaline in the Upper Cretaceous sandstones. Grains which show such characteristics are rare and most often rounded, suggesting that they were recycled.

The percentages of the three dominant tourmaline genetic groups (1-3) are similar in the successive sandstones, from Cenomanian to Santonian. The similarity between the samples is emphasized not only by the almost identical average composition of tourmaline grains (Fig. 11) and the occurrence of roughly akin colour varieties, but also by the comparable minor element content and the consistent presence of rare tourmaline types, such as grains with numerous sillimanite (fibrolite) inclusions. On the other hand, subtle differences between the tourmaline populations show that the source rocks changed slightly with time. The Turonian population is the most diverse and conspicuous against the background of the remaining ones. It contains calcic-group tourmaline indicating a contribution of calc-silicate rocks or metacarbonates, and dravite suggesting supply from ultramafic rocks. This is in agreement with the presence of pyrope and grossular-rich garnet in the Turonian sandstones (Biernacka and Józefiak, 2009).

The overwhelming dominance of metamorphic tourmaline among overall abundant heavy minerals, and the occurrence of rutile, garnet, staurolite, sillimanite and kyanite in the heavy mineral spectra suggest that at least a part of quartz grains, by inference, came also from the same ultimate source, i.e. metamorphic rocks. This is further corroborated by the high abundance of metamorphic polycrystalline quartz, particularly in the coarse-grained sediments. Part of the monocrystalline quartz grains probably came from acid volcanic rocks devoid of tourmaline, which is suggested by rare volcanic rock fragments and the shape of some grains.

\section{FIRST CYCLE SEDIMENTS?}

The average chemical composition of the detrital tourmaline largely meshes with that of tourmaline from the Góry Sowie Massif and its surrounding areas and differs substantially from the composition of Karkonosze-Izera tourmaline (Fig. 11). A certain resemblance to tourmalines from other Sudetic regions (Strzelin Massif, Orlica-Śnieżnik Massif) is also evident although this subgroup of the detrital tourmaline is quantitatively not abundant. Distinct fibrolite-containing tourmaline is known from sillimanite-bearing mica schists of the Strzelin Massif (Fore-Sudetic Block) yet this tourmaline appears green under the microscope (Bereś, 1969). Sillimanite-bearing green tourmaline does occur among the detrital grains but it is exceptionally rare. The source of the brown sillimanite-containing tourmaline lay elsewhere, possibly in other sillimanite-bearing rocks of the Fore-Sudetic Block, at present largely covered by Cenozoic deposits. All of this points rather to the Eastern Sudetic Island as the dominant source area. Indeed, the Upper Cretaceous sandstones of the North Sudetic Synclinorium form wedges situated in the eastern part of the unit (Fig. 2D). They thin westwards and pass into marls or mudstones (Scupin, 1912-13; Milewicz, 1979, 1997), and in consequence document a dominant northwestwards direction of sediment supply. 
Several observations seem to justify the delivery of detritus directly from weathered crystalline rocks and the deposition of this detritus within the sedimentary basin, i.e. the first-cycle nature of the Cretaceous sandstones. The predominance of subangular quartz and angular tourmaline grains indicates relatively short transport and contradicts multiple recycling. Variscan crystalline rocks did occur at the surface in some parts of the Bohemian Massif in the Late Cretaceous (e.g., Gierwielaniec and Turnau-Morawska, 1961; Gorczyca-Skała, 1977; Uličný et al., 2009b). In the Sudetes, they constituted the basement of a part of the Cenomanian and Turonian deposits.

However, this first-cycle sedimentation model poses a number of problems. The scenario that only the Eastern Sudetic Island delivered detritus to the North Sudetic Basin is difficult to accept in light of many regional studies (Scupin, 1912-13, 1936; Andert, 1934; Milewicz, 1965, 1997, 1998; Skoček and Valečka, 1983; Uličný, 2001; Uličný et al., 2009a). The rare occurrence of granitic tourmaline is problematic taking into account the occurrence of several relatively large granite plutons in the vicinity of the North Sudetic Basin (Fig. 1). This is even more problematic if a longer time span from Cenomanian to Santonian is considered. The lack of conspicuous trends in the tourmaline composition reflecting the changes in palaeogeography remains unclear. The consistent presence of mature quartz-rich arenites instead of a gradual contribution of less mature sandstones as erosion exposed the deeper parts of crystalline massifs is surprising. The Coniacian/Santonian sandstones from the Nysa Trough, situated not further than $100 \mathrm{~km}$ towards the south-east, are immature lithic/arkosic arenites (Jerzykiewicz, 1971). These problems could be resolved if we assume that some of the metamorphic and igneous massifs known from the present-day exposure were not at the surface in the Late Cretaceous. These were hidden under a thick sedimentary cover, and sediments from the latter were recycled into the North Sudetic Basin.

\section{SEDIMENT RECYCLING}

Recent sedimentological research of the Cretaceous Bohemian Basin (Uličný et al., 2009a) and a thermochronological study of the Karkonosze granite (Danišík et al., 2010) showed that since the latest Turonian the Karkonosze-Izera Massif has undergone rapid exhumation, resulting in the removal of as much as $6 \mathrm{~km}$ of overburden in some $15 \mathrm{Myr}$. Yet from the interpretation of the detrital tourmaline it follows that the massif did not supply granitic material to the nearby North Sudetic Basin. Because the Karkonosze Pluton was exposed in the Permian (or even Late Carboniferous) for the first time (Dziedzic, 1961; Prouza and Tásler, 2001; Mazur et al., 2010), it must have been eroded and covered by siliciclastic rocks prior to the Late Cretaceous (mid-Cenomanian). These rocks are assumed as source rocks for the North Sudetic Basin in the Late Cretaceous. The age of these siliciclastic rocks remains unknown, but they certainly contained grains which were derived from medium/high grade metamorphic rocks.

Moreover, Aramowicz et al. (2006) - on the basis of apatite fission-track data - suggested the occurrence of a thick sedimentary cover on the Gory Sowie Massif in the Late Cretaceous. A Late Carboniferous/Permian age of this sedimentary cover was assumed (Aramowicz et al., 2006; Mazur et al., 2010). As these hypothetical sedimentary rocks had been removed completely by the Oligocene, only siliciclastic rocks filling the Sudetic sedimentary basins may yield clues to their composition. The observation that Permian sandstones from the Intra-Sudetic Basin contain a distinct assemblage of detrital garnet which is similar to that in Sudetic Turonian sandstones generally fits this hypothesis. It is possible that, at the end of the Variscan epoch, rivers carried detrital material outside the rapidly eroded Bohemian Massif, and buried some subsided crystalline massifs. The detrital material could partly be recycled from the interior of the Bohemian Massif, e.g. the Moldanubian Zone. A large part of the detrital tourmaline resembles tourmaline from abyssal pegmatites in granulitic rocks of the Bohemian Massif, with respect to the very low content of $\mathrm{F}$, a significantly vacant $\mathrm{X}$-site and the high content of Al (Cempírek and Novák, 2010). Moreover, some Ca-rich tourmaline grains (Table 1) show compositions surprisingly similar to tourmaline from the melasyenite Třebíč Pluton situated in the Moldanubian Zone of the Bohemian Massif (Novák et al., 2011).

There are few direct petrographic indicators of grain redeposition in the case studied. The occurrence of two contrasting types of tourmaline grain - angular fragments alongside well-rounded spherical grains - suggests multi-cycle origin of the latter, i.e. their redeposition from older sedimentary or low-grade metasedimentary rocks. The co-occurrence of angular and rounded quartz grains also suggests recycling. Nonetheless, the minority of rounded grains is not a compelling argument for large-scale recycling. The similar composition - in terms of shape and colour - of the Triassic and Cretaceous tourmaline populations (Figs. 7 and 8) is more convincing. Triassic siliciclastic rocks undoubtedly contributed grains into Cretaceous sandstones, particularly rounded grains and tourmaline with sillimanite inclusions. The author's unpublished data from Triassic sandstones of the Wlen Graben show that the amount of such grains is slightly higher than in the Cretaceous sandstones.

The weakest point of this recycling model is the evident textural immaturity of the Cretaceous sandstones, that is the considerable amount of subangular grains, higher than in the underlying Triassic sandstones (Mroczkowski, 1972). Nonetheless, the Cretaceous sandstones could have inherited the unabraded grains from a sedimentary predecessor other than Triassic sandstones, for example Permian siliciclastic rocks. They are also texturally immature (Dziedzic, 1961). Short transport (not longer than $50 \mathrm{~km}$ ) and rapid deposition without longer reworking in the coastal environment could not have caused greater abrasion, particularly of fine or medium-sized particles. In addition, lithic granules and pebbles - even if originally rounded - would have disintegrated into subangular/ subrounded grains after a longer exposure to weathering. Finally, it cannot be totally dismissed that some angular/ subangular grains were supplied directly from a crystalline source. However, the delivery of detritus from siliciclastic rocks explains the high abundance of quartz grains.

The similar tourmaline populations in the successive sandstones - from Cenomanian to Santonian - suggest that the sedimentary rocks covering the Eastern and Western Sudetic Islands did not differ remarkably with regard to their lithological composition. On the other hand, the subtle differences between 
the tourmaline populations indicate that successive sedimentary layers were exposed. The Turonian sandstones originated from partly different source rocks than the Cenomanian sandstones. The Coniacian sandstones are not identical to the Turonian rocks, although their similar tourmaline populations suggest that Turonian sandstones contributed particles into Coniacian arenites. Milewicz $(1965,1997)$ has already suggested that the eastern part of the North Sudetic Basin was eroded during the late Coniacian.

It may be concluded that the successive - Cenomanian to Santonian - coarse-grained sandstones reflect gradual exhumation of the surrounding massifs covered by thick siliciclastic deposits, but do not record the final exposure of crystalline rocks.

\section{INVERSION}

The Late Cretaceous (latest Turonian-Campanian) was a time of intensive intraplate thrusting and basin inversion in Central Europe (Voigt et al., 2008a; Kley and Voigt, 2011). Former sedimentary basins were inverted supplying detrital material to the newly formed inversion-related basins. One of the best examples of the gradual inversion of a basement high associated with the contemporaneous filling of a nearby sedimentary basin is the Harz area and the adjoining Subhercynian Basin (Voigt et al., 2006; Voigt et al., 2008a). The well-exposed $2500 \mathrm{~m}$ thick fill of the Subhercynian Basin records uplift of the surrounding source areas and the final exhumation of the Harz crystalline core (Voigt et al., 2006; von Eynatten et al., 2008). This Late Cretaceous pulse of tectonic deformation affected also the Bohemian Massif and was recorded by increased sediment supply into sedimentary basins situated within the massif and at its margins (Uličný et al., 2009a; Niebuhr et al., 2011).

Several lines of evidence suggest that the Coniacian and Santonian sandstones of the North Sudetic Synclinorium are also inversion-related deposits. Their substantial thickness exceeds several times that of the Cenomanian and Turonian silicicklastic rocks (Milewicz, 1997). Considerable changes in basin architecture were interpreted for Coniacian and Santonian times (Milewicz, 1965, 1997; Leszczyński, 2010). Apatite fission track data from the surrounding massifs indicate increased uplift since the Latest Turonian (Aramowicz et al., 2006; Danišík et al., 2010). This Late Cretaceous inversion episode did not result in the final exhumation of crystalline rocks. Generally, only a few basement uplifts in Central Europe reached the surface during the Late Cretaceous inversion episode (Voigt et al., 2008a).

\section{FINAL REMARKS}

Upper Cretaceous sandstones of the North Sudetic Synclinorium owe their quartz-rich composition to a number of various factors: weathering under a subtropical climate, low-relief topography, source lithology, and diagenesis. These factors operated with variable intensity, resulting in a similar product.

The Cenomanian sandstones, which were deposited after a long hiatus encompassing the Jurassic and Early Cretaceous, originated from regoliths covering Sudetic land areas. Uličný et al. (2009b) documented a peneplain in the northwestern Bohemian Massif with the deepest valleys less than $90 \mathrm{~m}$ below the surrounding terrain; in some places kaolinite-rich regoliths up to several tens of metres thick are still preserved under Cretaceous rocks. Although such thick regoliths are not preserved in the Polish part of the Sudetes, their former occurrence in the Late Cretaceous is highly probable (Migon and LidmarBergström, 2002). Therefore, the composition of the Cenomanian sandstones was originally quartz-rich.

The less mature - subarkosic - composition of the Turonian sandstones indicates that, in the Turonian, erosion exposed less weathered rocks. The massive deposition of less mature feldspathic arenites at a regional scale (Jerzykiewicz, 1975; Wojewoda, 1997; Uličný, 2001; Götze and Siedel, 2007; Niebuhr et al., 2011) could have been also caused by a slightly drier climate or an increased erosion rate (a low relative sea-level was interpreted for the mid-Turonian - Uličný and Čech in Voigt et al., 2008b; Uličný et al., 2009a).

The Coniacian sandstones of the North Sudetic Synclinorium, the most mature among the Cretaceous siliciclastic rocks, are composed almost exclusively of quartz grains associated with ultrastable heavy minerals (tourmaline, zircon, rutile). These sandstones must have been derived from quartz-rich source rocks. Presumably, the Turonian sandstones also contributed particles into the Coniacian sandstones.

The Santonian (and a part of the Coniacian) sandstones contain several percent of kaolinite coming from the destruction of less resistant grains during early diagenesis (Górniak, 1991). Originally, after deposition, these sandstones must have been sublithic/subarkosic in composition. In this regard the mineralogical maturity of the Santonian (and a part of the Coniacian) sandstones is a combined effect of pre- and post-depositional processes.

\section{SUMMARY AND CONCLUSIONS}

Upper Cretaceous quartz arenites that fill the eastern part of the North Sudetic Synclinorium show high compositional but low textural maturity. The sandstones are rich in heavy minerals (up to $3.5 \mathrm{wt} . \%$ ), among which tourmaline is the predominant species. Although these siliciclastic rocks have been interpreted for years as derived largely from the nearby granitoid massifs, new heavy mineral data do not support this hypothesis. On the contrary, the entire several hundred metres-thick sandstone succession contains abundant angular tourmaline grains which originated from various metamorphic rocks. The content of granitic tourmaline is remarkably low and does not change with time. Thus, large Sudetic granite plutons such as the Karkonosze and Strzegom-Sobótka massifs must have been covered by sediments in the Late Cretaceous and exhumed later than in the mid-Santonian.

Although the chemical composition of the detrital tourmaline resembles that of tourmaline from the Góry Sowie Massif, published fission-track apatite data and the consistent quartz-rich composition of the Cretaceous sandstones indicate that this massif was also covered by sediments in the Late Cretaceous. Possibly, at the end of the Variscan epoch and in the Mesozoic, rivers draining the interior of the Bohemian Massif 
buried some eroded massifs on its periphery. It follows that the successive - Cenomanian to Santonian - clastic deposits of the North Sudetic Synclinorium reflect the gradual exhumation of the Karkonosze-Izera Massif and the Góry Sowie Massif, but do not record the final exposure of crystalline rocks. Since the latest Turonian, this exhumation corresponded to the Late Cretaceous inversion episode in Central Europe.

Upper Cretaceous sandstones of the North Sudetic Synclinorium owe their quartz-rich composition to a combination of various factors, which operated with variable intensity: weathering under a subtropical climate, low-relief topography, quartz-rich source lithology, and diagenetic alteration of less resistant grains.

The textural immaturity of the Upper Cretaceous sandstones, i.e. the high content of unabraded grains, can be explained as inheritance from immature sedimentary source rocks. Thus, the occurrence of unabraded grains as a main indicator of first-cycle deposition may be misleading.

Acknowledgements. The contribution benefited greatly from painstaking reviews by R. Schöner and M. Novák. The sandstones analysed in this study were sampled in collaboration with M. Józefiak, who also separated heavy minerals and to whom I extend my sincere thanks. I am indebted to the owners of active quarries (OSIECZNICA Sp. $\mathrm{z}$ o.o., SURMIN-KAOLIN S.A., Kopalnie Piaskowca S.A. "Rakowiczki" and "Żerkowice") for their permission to visit these places. I am grateful to P. Dzierżanowski and L. Jeżak (Warsaw University) for their help with microprobe analyses. I also thank P. Raczyński for indicating the Twardocice locality and discussions.

\section{REFERENCES}

ALEKSANDROWSKI P., KRYZA R., MAZUR S. and ŻABA J. (1997) Kinematic data on major Variscan strike-slip faults and shear zones in the Polish Sudetes, northeast Bohemian Massif. Geol. Mag., 133: 727-739

ALEXANDROWICZ S. W. (1976) - Foraminifera from the brackish Santonian deposits in the North Sudetic Basin (Western Poland). Ann. Soc. Geol. Pol., 46: 183-195.

ALEXANDROWICZ S. W. (1971) - Stratigraphy and microfauna of the Upper Cenomanian in the North Sudetic Basin (in Polish with English summary). Ann. Soc. Geol. Pol., 41: 321-335.

ANDERT H. (1934) - Die Fazies in der sudetischen Kreide unter besonderer Berücksichtigung des Elbsandsteingebirges. Z. dt. geol. Ges., 86: 617-637.

ARAMOWICZ A., ANCZKIEWICZ A. and MAZUR S. (2006) - Fission-track dating of apatite from the Góry Sowie Massif, Polish Sudetes, NE Bohemian Massif: implications for post-Variscan denudation and uplift. N. Jb. Miner. Abh., 182: 221-229.

AVIGAD D., SANDLER A., KOLODNER K., STERN R. J., MCWILLIAMS M., MILLER N. and BEYTH M. (2005) - Mass-production of Cambro-Ordovician quartz-rich sandstone as a consequence of chemical weathering of Pan-African terranes: environmental implications. Earth Planet. Sc. Lett., 240: 818-826.

BAŁAZIŃSKA J. and BOSSOWSKI A. (1979) - Deep geological structure of central and western parts of the North-Sudetic Synclinorium: Some new data (in Polish with English summary). Kwart. Geol., 23 (3): 309-321.

BEREŚ B. (1969) - Petrography of granite in the environments of Strzelin (in Polish with English summary). Arch. Miner., 28: 5-105.

BERNET M., KAPOUTSOS D. and BASSET K. (2007) - Diagenesis and provenance of Silurian quartz arenites in south-eastern New York State. Sediment. Geol., 201: 43-55.

BIERNACKA J. and JÓZEFIAK M. (2009) - The Eastern Sudetic Island in the Early-to-Middle Turonian: evidence from heavy minerals in the Jerzmanice sandstones, SW Poland. Acta Geol. Pol., 59: 545-565.

BOSSOWSKI A. and BAŁAZIŃSKA J. (1982) - Tectonic-structural evolution of the North-Sudetic Synclinorium (in Polish with English summary). Biul. Inst. Geol., 341: 163-167.

BURIÁNEK D. and NOVÁK M. (2007) - Compositional evolution and substitutions in disseminated and nodular tourmaline from leucocratic granites: Examples from the Bohemian Massif, Czech Republic. Lithos, 95: 148-154.

CARACCIOLO L., le PERA E., MUTO F. and PERRI F. (2011) - Sandstone petrology and mudstone geochemistry of the Peruc-Korycany
Formation (Bohemian Cretaceous Basin, Czech Republic). Internat. Geol. Rev., 53: 1003-1031.

CEMPÍREK J. and NOVÁK M. (2010) - Field stop 4: Starkoč near Č́slav, Kutná Hora Unit - Abyssal pegmatite of the BBe subclass. Acta Miner.-Petrograph., 6: 25-29.

DALLMEYER R. D., FRANKE W. and WEBER K., eds. (1995) Pre-Permian geology of Central and Eastern Europe. Springer-Verlag. Berlin.

DANIŠÍK M., MIGOŃ P., KUHLEMANN J., EVANS N. J., DUNKL I. and FRISCH W. (2010) - Thermochronological constraints on the long-term erosional history of the Karkonosze Mts., Central Europe. Geomorphology, 117: 78-89.

DUTROW B. L. and HENRY D. J. (2011) - Tourmaline: a geologic DVD. Elements, 7: 301-306.

DZIEDZIC K. (1961) - Lower Permian of the Intra-Sudetic Basin (in Polish with English summary). Stud. Geol. Pol., 6: 1-121.

FALCON-LANG H. J., KVAČEK J. and ULIČNÝ D. (2001) - Fire-prone communities and palaeoclimate of a Late Cretaceous fluvial to estuarine environment, Pecínov quarry, Czech Republic. Geol. Mag., 138: 563-576.

GIERWIELANIEC J. and TURNAU-MORAWSKA M. (1961) - Origin of glauconite in the Cretaceous transgressive sediments of Kudowa-Spalona region (Sudeten Mts.) (in Polish with English summary). Arch. Miner., 25: 261-279.

GORCZYCA-SKAŁA J. (1977) - Geologic structure of the Wlen Graben (in Polish with English summary). Geol. Sudet., 12: 71-101.

GÓRNIAK K. (1991) - The influence of sedimentary conditions and of early diagenesis on mineral composition of alluvial sediments (exemplified by Santonian sandy-clayey sediments of the North Sudetic Trough) (in Polish with English summary). Pr. Geol., 136: 1-95.

GÖTTE T. and RICHTER D. K. (2006) - Cathodoluminescence characterization of quartz particles in mature arenites. Sedimentology, 53: $1347-1359$.

GÖTZE J. and SIEDEL H. (2007) - A complex investigation of building sandstones from Saxony (Germany). Mater. Character., 58: 1082-1094.

HAWTHORNE F. C. and HENRY D. J. (1999) - Classification of the minerals of the tourmaline group. Eur. J. Miner., 11: 201-215.

HAY W. W., DECONTO R., WOLD C. N., WILSON K. M., VOIGT S., SCHULTZ M., WOLD-ROSSBY A., DULLO W. C., RONOV A. B., BALUKHOVSKY A. N. and SOEDING E. (1999) - Alternative global Cretaceous paleogeography. Geol. Soc. Am. Spec. Pap., 332: $1-47$. 
HENRY D. J. and DUTROW B. L. (1992) - Tourmaline in a low grade clastic metasedimentary rock: an example of the petrogenetic potential of tourmaline. Contrib. Miner. Petrol., 112: 203-218.

HENRY D. J. and GUIDOTTI C. V. (1985) - Tourmaline as a petrogenetic indicator mineral: an example from the staurolite-grade metapelites of NW Maine. Am. Miner., 70: 1-15.

HENRY D. J., NOVÁK M., HAWTHORNE F. C., ERTL A., DUTROW B. L., UHER P. and PEZZOTTA F. (2011) - Nomenclature of the tourmaline supergroup minerals. Am. Miner., 96: 895-913.

HUBERT J. F. (1962) - A zircon-tourmaline-rutile maturity index and the interdependence of the composition of heavy mineral assemblages with the gross composition and textures of sandstones. J. Sed. Petrol., 32: $440-450$.

JANECZEK J. (1985) - Typomorphic minerals of pegmatites from the Strzegom-Sobótka Granitic Massif (in Polish with English summary). Geol. Sudet., 20: 1-82.

JERZYKIEWICZ T. (1971) - A flysch/littoral succession in the Sudetic Upper Cretaceous. Acta Geol. Pol., 21: 165-199.

JERZYKIEWICZ T. (1975) - Pozycja geologiczna osadów grónokredowych depresji śródsudeckiej i rowu Nysy Kłodzkiej. In: Przewodnik 47 Zjazdu Polskiego Towarzystwa Geologicznego 22-24 czerwca 1975, Świdnica (ed. A. Grocholski): 227-252. Wyd. Geol., Warszawa.

JERZYKIEWICZ T. and WOJEWODA J. (1986) - The Radków and Szczeliniec sandstones: an example of giant foresets on a tectonically controlled shelf of the Bohemian Cretaceous Basin (Central Europe). Can. Soc. Petrol. Geol., Mem., 2: 1-15.

JOHNSSON M. J., STALLARD R. F., LUNDBERG N. (1991) - Controls on the composition of fluvial sands from a tropical weathering environment: sands of the Orinoco drainage basin, Venezuela and Colombia. Bull. Geol. Soc. Am., 103: 1622-1647.

JÓZEFIAK M. (2007) - Heavy minerals in selected Upper Cretaceous sandstones of the North Sudetic Synclinorium (in Polish). M.Sc. Thesis, University of Poznań

KARWOWSKI Ł. (1973) - Greisens of the Izera Upland (Sudetes) (in Polish, with English summary). Acta Geol. Pol., 23: 325-340.

KOZLOWSKI K. (1974) - Crystalline schists and leucogranites of the Stara Kamienica-Świeradów Zdrój Belt (Western Sudetes) (in Polish with English summary). Geol. Sudet., 9: 7-100.

KLEY J. and VOIGT T. (2011) - Late Cretaceous intraplate thrusting in central Europe: Effect of Africa-Iberia-Europe convergence, not Alpine collision. Geology, 36: 839-842.

KRENZ O., WALTER H., BRAUSE H., HOTH K., KOZDRÓJ W., CYMERMAN Z., OPLETAL M. and MRÁZOVÁ Š. (2000) - Geological map Lausitz-Jizera-Karkonosze 1: 100000 (without Cainozoic sediments). Sächsisches LUG, Państwowy Instytut Geologiczny, Český Geologický Ustav.

KRYNINE P. D. (1946) - The tourmaline group in sediments. J. Geol., 65: $65-87$

KRYZA R. (1977) - Cordierite-bearing pegmatite in serpentinites of the environs of Lubachów (Sowie Góry Mts., Sudetes) (in Polish with English summary). Ann. Soc. Geol. Pol., 47: 247-263.

KRYZAR. (1981) - Migmatization in gneisses of northern part of the Góry Sowie, Sudetes (in Polish with English summary). Geol. Sudet., 14: $7-100$

KUŽVART M. and KONTA J. (1968) - Kaolin and laterite weathering crusts in Europe. Acta Univ. Carol., Geologia, 1-2: 1-19.

LESZCZYŃSKI S. (2010) - Coniacian-?Santonian paralic sedimentation in the Rakowice Małe area of the North Sudetic Basin, SW Poland: Sedimentary facies, ichnological record and palaeogeographical reconstruction of an evolving marine embayment. Ann. Soc. Geol. Pol., 80: $1-24$

LIS J. and SYLWESTRZAK H. (1986) - Minerals of Lower Silesia (in Polish). Wyd. Geol., Warszawa.

MAZUR S., ALEKSANDROWSKI P., TURNIAK K., MASTALERZ K., GÓRECKA-NOWAK A., KUROWSKI L., KRZYWIEC P., ŻELAŹNIEWICZ A. and FANNING M. C. (2010) - Uplift and late orogenic deformation of the Central European Variscan belt as revealed by sediment provenance and structural record in the Carboniferous foreland basin of western Poland. Internat. J. Earth Sc. 99: $47-64$
MIGOŃ P. and LIDMAR-BERGSTRÖM K. (2002) - Deep weathering through time in central and northwestern Europe: problems of dating and interpretation of of geological record. Catena, 49: 25-40.

MILEWICZ J. (1965) - Facies of the Upper Cretaceous in the eastern part of the North Sudetic Basin (in Polish). Biul. Inst. Geol., 170: 15-80.

MILEWICZ J. (1970) - The Cretaceous of the Jerzmanice Graben (in Polish with English summary). Biul. Inst. Geol., 19: 37-66.

MILEWICZ J. (1971) - Relation between the North-Sudetic and East-Branderburg Cretaceous formations (in Polish with English summary). Kwart. Geol., 15 (1): 122-136.

MILEWICZ J. (1979) - Distribution of Cretaceous rocks in the North-Sudetic Basin (in Polish with English summary). Kwart. Geol., 23 (4): 819-826.

MILEWICZ J. (1985) - A proposal of formal lithostratigraphic nomenclature for the North Sudetic Basin sedimentary fill (in Polish with English summary). Prz. Geol., 33 (5): 385-390.

MILEWICZ J. (1988) - Cretaceous macrofauna in Weggliniec IG 1 borehole (in Polish with English summary). Kwart. Geol., 32 (2): 389-404.

MILEWICZ J. (1997) - Upper Cretaceous of the North Sudetic Depression (litho- and biostratigraphy, paleogeography, tectonics and remarks on raw materials) (in Polish with English summary). Pr. Geol.-Miner., 61: $1-59$.

MILEWICZ J. (1998) - Distribution of Coniacian sandstones in the North Sudetic Basin (in Polish with English summary). Pr. Geol.-Miner., 64: 101-109.

MORAL CARDONA J.P., GUTIÉRREZ MAS J.M., SÁNCHEZ BELLÓN A., LÓPEZ-AGUAYO F. and CABALLERO M.A. (1997) - Provenance of multicycle quartz arenites of Pliocene age at Arcos, southwestern Spain. Sediment. Geol., 112: 251-262.

MROCZKOWSKI J. (1972) - Sedimentation of the Bunter in the North-Sudetic Basin (in Polish with English summary). Acta Geol. Pol., 22: 351-378.

NASCIMENTO M., DOS SANTOS GÓES A. M., BUENANO MACAMBIRA M. J. and BROD J. A. (2007) - Provenance of Albian sandstones in the Sno Luís-Grajaú Basin (northern Brazil) from evidence of $\mathrm{Pb}-\mathrm{Pb}$ zircon ages, mineral chemistry of tourmaline and palaeocurrent data. Sediment. Geol., 201: 21-42.

NIEBUHR B., WILMSEN M., CHELLOUCHE P., RICHARDT N. and PÜRNER T. (2011) - Stratigraphy and facies of the Turonian (Upper Cretaceous) Roding Formation at the southwestern margin of the Bohemian Massif (Southern Germany, Bavaria). Z. dt. Ges. Geowiss., 162: $295-316$.

NOVÁK M. and CEMPÍREK J., eds. (2010) - Granitic pegmatites and mineralogical museums in Czech Republic. Acta Miner.-Petrograph. (Field Guide Series), 6: 1-56.

NOVÁK M., POVONDRA P. and SELWAY J. B. (2004) Schorl-oxy-schorl to dravite-oxy-dravite tourmaline from granitic pegmatites; examples from the Moldanubicum, Czech Republic. Eur. J. Miner., 16: 323-333.

NOVÁK M., ŠKODA R., FILIP J., MACEK I. and VACULOVIČ T. (2011) - Compositional trends in tourmaline from intergranitic NYF pegmatites of the Třebič Pluton, Czech Republic: an electron microprobe, Mössbauer and LA-ICP-MS study. Can. Miner., 49: 359-380.

OBERC J. (1972) - Geology of Poland IV. Tectonics 2. The Sudetes and adjacent areas (in Polish). Wyd. Geol., Warszawa.

PETTIJOHN F. J., POTTER P. E. and SIEVER R. (1987) - Sand and sandstone (2nd ed.). Springer-Verlag, Berlin.

PIECZKA A. (1996) - Mineralogical study of Polish tourmalines (in Polish with English summary). Pr. Miner., 85: 1-79.

PIECZKA A. (2000) - A rare mineral-bearing pegmatite from the Szklary serpentinite massif, the Fore-Sudetic Block, SW Poland. Geol. Sudet., 33: $23-31$.

PIECZKA A. and KRACZKA J. (1988) - Tourmalines of the Strzegom Granitoid Massif. Miner. Pol., 19: 25-39.

PIECZKA A. and KRACZKA J. (1996) - X-ray and Mössbauer study of black tourmalines (schorls) from Szklary (Lower Silesia, Poland). Miner. Pol., 27: 33-40.

PIECZKA A., HEFLIK W., KRACZKA J. and GOŁĘBIOWSKA B. (1996) - X-ray and spectroscopic study of Mn-garnet and tourmaline from Jordanów, Lower Silesia (Poland). Miner. Pol., 27: 39-54. 
POVONDRA P., LANG M., PIVEC E. and ULRYCH J. (1998) - Tourmaline from the Přibyslavice peraluminous alkali-feldspar granite, Czech Republic. J. Czech Geol. Soc., 43: 3-8.

PROUZA V. and TÁSLER R. (2001) - Podkrkonošská pánev. In: Geologie a ložiska svrchnopaleozoických limnických pánví České republiky (eds. J. Pešek et al.): 128-166. Český geologický ústav, Praha.

SACHANBIŃSKI M., PIÓREWICZ R. and MICHALIK R. (2000) Heavy minerals in the serpentinite weathering cover of the Szklary Massif. Geol. Sudet., 33: 131-141.

SCUPIN H. (1912-1913) - Die Löwenberger Kreide und ihre Fauna. Palaeontographica, 6.

SCUPIN H. (1936) - Zur Palaeographie des sudetischen Kreidemeeres. Z. dt. geol. Ges., 88: 309-325.

SKOČEK V. and VALEČKA J. (1983) - Paleogeography of the Late Cretaceous Quadersandstein of Central Europe. Palaeogeogr. Palaeoclimatol. Palaeoecol., 44: 71-92.

SŁABY E. and KOZŁOWSKI A. (2005) - Composition of tourmalines from tin-tungsten-bearing country rock of the Variscan Karkonosze granitoid - a record of the wall rock and hydrothermal fluid interaction. N. J. Miner. Abh., 181: 245-263.

SUTTNER L. J. and BASU A. (1981) - Climate and the origin of quartz arenites. J. Sed. Petrol., 51: 1235-1246.

TEISSEYRE B. (1992) - Foraminifera of the Upper Cretaceous from the North Sudetic Basin (Western Sudetes) (in Polish with English summary). Pr. Geol.-Miner., 34: 1-78.

TRÖGER K.-A. (2004) - Cenomanian through Lower Coniacian events in the Upper Cretaceous of Saxony, Germany. Acta Geol. Pol., 54: 629-638.

ULIČNÝ D. (2001) - Depositional systems and sequence stratigraphy of coarse-grained deltas in a shallow-marine, strike-slip setting: the Bohemian Cretaceous Basin, Czech Republic. Sedimentology, 48: 599-628.

ULIČNÝ D. and ČECH S. (2008) - Bohemian Cretaceous Basin. In: The Geology of Central Europe (ed. T. McCann): 953-959. The Geological Society. London.

ULIČNÝ D., HLADÍKOVÁ J., ATTREP M., ČECH S., HRADECKÁ L. and SVOBODOVÁ M. (1997) - Sea-level changes and geochemical anomalies across the Cenomanian-Turonian boundary: Pecínov quarry, Bohemia. Palaeogeogr. Palaeoclimatol. Palaeoecol., 132: 265-285.

ULIČNÝ D., LAURIN J. and ČECH S. (2009a) - Controls on clastic sequence geometries in a shallow-marine transtensional basin: the Bohemian Cretaceous Basin, Czech Republic. Sedimentology, 56: 1077-1114.
ULIČNÝ D., ŠPIČÁKOVÁ L., GRYGAR R., SVOBODOVÁ M., ČECH S. and LAURIN J. (2009b) - Palaeodrainage systems at the basal unconformity of the Bohemian Cretaceous Basin: roles of inherited fault systems and basement lithology during the onset of basin filling. Bull. Geosc., 84: 577-610.

VALEČKA J. and SKOČEK V. (1991) - Late Cretaceous lithoevents in the Bohemian Cretaceous Basin, Czechoslovakia. Cret. Res., 12: 561-577.

Van HATTUM M. W. A., HALL R., PICKARD A. L. and NICHOLS G. J. (2006) - Southeast Asian sediments not from Asia: provenance and geochronology of north Borneo sandstones. Geology, 34: 589-592.

Van HINSBERG V. J., HENRY D. J. and DUTROW B. L. (2011a) - Tourmaline as a petrologic forensic mineral: a unique recorder of its geological past. Elements, 7: 327-332.

Van HINSBERG V. J., HENRY D. J. and MARSCHALL H. R. (2011b) Tourmaline: an ideal indicator of its host environments. Can. Miner., 49: $1-16$.

VOIGT T., WIESE F., von EYNATTEN H., FRANZKE H.-J. and GAUPP R. (2006) - Facies evolution of syntectonic Upper Cretaceous deposits in the Subhercynian Cretaceous Basin and adjoining areas (Germany). Z. dt. Ges. Geowiss., 157: 203-244.

VOIGT T., REICHERTER K., von EYNATTEN H., LITTKE R., VOIGT S. and KLEY J. (2008a) - Sedimentation during basin inversion. In: Dynamics of Complex Sedimentary Basins. The example of the Central European Basin System (eds. R. Littke, U. Bayer, D. Gajewski and S. Nelskamp): 211-232. Springer, Berlin, Heidelberg.

VOIGT S., WAGREICH M., SURLYK F., WALASZCZYK I., ULIČNÝ D., ČECH S., VOIGT T., WIESE F., WILMSEN M., NIEBUHR B., REICH M., FUNK H., MICHALÍK J., JAGT J. W. M., FELDER P. J. and SCHULP A. S. (2008b) - Cretaceous. In: The Geology of Central Europe (ed. T. McCann): 923-997. The Geological Society. London.

Von EYNATTEN H., VOIGT T., MEIER A., FRANZKE H.-J. and GAUPP R. (2008) - Provenance of Cretaceous clastics in the Subhercynian Basin: constraints to exhumation of the Hartz Mountains and timing of inversion tectonics in Central Europe. Internat. J. Earth Sc., 97: 1315-1330.

WOJEWODA J. (1997) - Upper Cretaceous littoral-to-shelf succession in the Intrasudetic Basin and Nysa Trough, Sudety Mts. In: Obszary źródłowe: zapis w osadach (ed. J. Wojewoda): 81-96. WIND. Wrocław.

ZIEGLER P. A. (1990) - Geological atlas of Western and Central Europe. Shell International Petroleum. Maatschappij. The Hague. 